\title{
ARTICLE
}

Cite this: DOI: 10.1039/x0xx00000x

Received 00th January 2012

Accepted 00th January 2012

DOI: $10.1039 / \times 0 \times x 00000 x$

www.rsc.org/

\section{Stereoselective Synthesis of 2-Acetamido-1,2- dideoxynojirimycin (DNJNAc) and Ureido-DNJNAc Derivatives as New Hexosaminidase Inhibitors}

\author{
Alex de la Fuente, ${ }^{a}$ Teresa Mena-Barragán, ${ }^{\mathrm{b}}$ Ronald A. Farrar-Tobar, ${ }^{\mathrm{a}}$ \\ Xavier Verdaguer, ${ }^{\mathrm{a}, \mathrm{c}}$ José M. García Fernández, ${ }^{\mathrm{d}}$ Carmen Ortiz Mellet, ${ }^{*}, \mathrm{~b}$ \\ Antoni Riera, ${ }^{, a, c}$
}

\begin{abstract}
2-Acetamido-1,2-dideoxyiminosugars are selective and potent inhibitors of hexosaminidases and therefore show high therapeutic potential for the treatment of various diseases, including several lysosomal storage disorders. A stereoselective synthesis of 2-acetamido-1,2dideoxynojirimycin (DNJNAc), the iminosugar analog of $\mathrm{N}$-acetylglucosamine, with high overall yield is here described. This novel procedure further allowed accessing ureidoDNJNAc conjugates through derivatization of the endocyclic amine on a key pivotal intermediate. Remarkably, some of the ureido-DNJNAc representatives behaved as potent and selective inhibitors of $\beta$-hexosaminidases, including the human enzyme, being the first examples of neutral $\mathrm{sp}^{2}$-iminosugar-type inhibitors reported for these enzymes. Moreover, the amphiphilic character of the new ureido-DNJNAc is expected to confer better drug-like properties.
\end{abstract}

\section{Introduction.}

Since the isolation of nojirimycin in 1966, iminosugars - sugar analogs where the oxygen ring atom has been replaced by a nitrogen - have attracted an exponential interest as mimics of the transition state of the enzymatic hydrolysis of glycosidic substrates. ${ }^{1,2}$ Their ability to act as inhibitors of a great diversity of carbohydrate processing enzymes, including glycosidases, glycosyl transferases, nucleoside-processing enzymes and glycogen phosphorylases, and the broad variety of biological and pathological processes in which carbohydrates are involved make iminosugars invaluable tools in glycobiology and promising candidates for the development of glycotherapies..$^{3-5}$ In fact, some iminosugars are already marketed drugs, such as miglitol (Glyset) and $N$-butyl-1-deoxynojirimycin (Zavesca), used for the treatment of type II diabetes mellitus and type 1 Gaucher disease respectively. ${ }^{6}$

Iminosugars reduced at $\mathrm{C}-1$ and bearing an acetamido group at the position equivalent to $\mathrm{C}-2$ in the parent monosaccharides, namely 2-acetamido-1,2dideoxyiminosugars, have been the focus of considerable attention in recent years. Several representatives of acetamido iminosugars, for instance pochonicine $(\mathbf{1})^{7}$, siastatine B (2), ${ }^{8}$ or nagstatine (3) ${ }^{9,10}$ have been isolated from natural sources while derivatives from those and other compounds have been obtained by chemical synthesis ${ }^{11,12}$. Most of these representatives are piperidine derivatives, such as 2-acetamido-1,2-dideoxynojirimycin (DNJNAc, 4) ${ }^{13-16}$ and its manno (DMJNAc, 5) ${ }^{14,17}$ or galacto epimers (DGJNAc, 6), ${ }^{18,19}$ although acetamido iminosugars with five- (e.g. 7 $)^{20,21}$ or seven-membered ring skeletons (e.g. 8) ${ }^{22}$ have also been described. Several of these compounds have proven to be highly selective inhibitors of hexosaminidases - the enzymes cleaving off amino sugar residues from oligosaccharides and glycoconjugates - with inhibition constant $\left(K_{\mathrm{i}}\right)$ values in the low micromolar to nanomolar range. This property makes them potentially useful in the treatment of several diseases involving abnormal levels of $O$-linked glucosamine (GlcNAc) in glycoproteins, including diabetes, Parkinson's, osteoarthritis, and some cancers. ${ }^{23-}$ 27 Furthermore, at subinhibitory concentrations competitive inhibitors of the hexosaminidases are able to promote the correct folding of mutant disease-associated lysosomal enzymes, thus bearing promise for the development of pharmacological chaperone therapies ${ }^{28}$ against some lysosomal storage disorders. ${ }^{20,29-31}$ Many studies have addressed the mechanism of action of these compounds, showing that the acetamido group is essential for their activity and selectivity. ${ }^{32-34}$

Most synthetic approaches to iminosugars are based on the chiral pool thus making these processes rather long. ${ }^{35-39}$ This is also the case for acetamido iminosugars, ${ }^{13,16,40,41}$ with a few exceptions limited to the 
stereoselective synthesis of 2-acetamido-1,2dideoxyallonojirimycin (DAJNAc, 9) ${ }^{42}$ and the manno diastereomer DMJNAc (5). ${ }^{17}$ Herein, we report a new stereoselective total synthesis of the gluco counterpart DNJNAc (4) and its regioisomer 3-acetamido-1,3dideoxyaltronojirimycin (29). Moreover, the preparation of a series of ureido-DNJAc derivatives as examples of 2-acetamido $\mathrm{sp}^{2}$-iminosugars, has also been accomplished. Characterized by the incorporation of a pseudoamide-type nitrogen atom with high $\mathrm{sp}^{2}$ hybridation character in the ring ${ }^{43-45}$, this subtype of glycomimetics, from which nagstatine $\mathbf{3}$ can be considered a natural representative, has previously shown an unprecedented potential for fine tuning the inhibitory potency and selectivity towards glycosidases by modulating the basicity of the $N$-functionality and the nature of the exocyclic moiety. ${ }^{46}$ In our case, the evaluation of the new ureido-DNJNAc against a panel of glycosidases allowed the identification of hexosaminidase inhibitors with an amphiphilic character and a greatly reduced basicity, features that make these compounds better suited as drug candidates.<smiles>CC(C)NC[C@@H]1[C@H](O)[C@@H](O)[C@@H]2[C@@H](O)C[C@@H](CO)N21</smiles><smiles>CCN[C@H]1c2nc(CC(=O)O)cn2[C@@H](CO)[C@@H](O)[C@@H]1O</smiles><smiles>C#CN[C@@H]1CN[C@H](CO)[C@@H](O)[C@@H]1O</smiles><smiles>CC(C)N[C@@H]1CN[C@H](CO)[C@H](O)[C@H]1O</smiles><smiles>CC(=O)N[C@@H]1CN[C@H](CO)[C@H](O)[C@H]1O</smiles>

DNJNAc, 4<smiles>CNC1CN[C@@H](CO)[C@@H]1O</smiles><smiles>CNC1CNCC(O)[C@H](O)[C@@H]1O</smiles>

LABNAc, 7<smiles>CC(C)N[C@H]1CN[C@H](CO)[C@@H](O)[C@H]1O</smiles>

DAJNAc, 9

Figure 1. Structure of some acetamido iminosugars.

\section{Results and discussion}

Our approach to DNJNAc, 4 and the ureido-DNJNAc derivatives $\mathbf{1 0}$ is shown in Scheme 1. An appropriate protecting group scheme was needed to introduce the urea fragment in the last steps. The protected compounds were prepared by introducing the amino function by nucleophilic ring opening of an epoxide or a cyclic sulfate obtained from the key intermediate 11, which is readily accessible by Sharpless asymmetric epoxidation of 2,4-pentadien-1-ol. ${ }^{47}$ This intermediate has been widely used for the synthesis of various iminosugars ${ }^{17,48-}$ 50 including our recent synthesis of DAJNAc (9). ${ }^{42}$

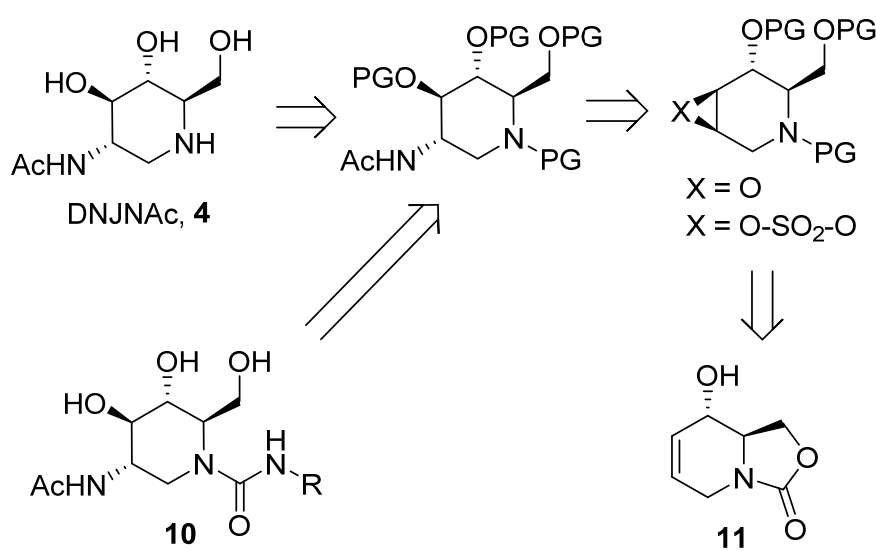

Scheme 1. Retrosynthetic analysis for the preparation of DNJNAc (4) and ureido-DNJNAc conjugates (10) from the common bicyclic precursor 11.

Optically pure carbamate $\mathbf{1 1}$ was prepared in multigram scale from penta-1,4-dien-3-ol, and the allylic alcohol group was subsequently protected as the corresponding benzyl ether 12. ${ }^{48}$ We first considered the epoxidation of the double bond in $\mathbf{1 2}$ followed by regioselectively ringopening by azide anion to introduce the amino substituent. Deceivingly, classical methodologies using $m$-chloroperoxybenzoic acid (MCPBA) or $\mathrm{H}_{2} \mathrm{O}_{2}$ proved inefficient while harsher oxidant methods such as $\mathrm{CF}_{3} \mathrm{CO}_{3} \mathrm{H}^{51,52}$ or oxone ${ }^{49}$ generated inseparable 1:1 mixtures of the corresponding epoxides in moderate yields. We hypothesized that the rigid bicyclic skeleton of 12 was probably responsible for the low reactivity observed. However, although hydrolysis of the cyclic carbamate by treatment with $6 \mathrm{M} \mathrm{NaOH}$ at reflux, followed by in situ Cbz-protection of the endocyclic amine afforded the monocylic derivative $\mathbf{1 3}$ in satisfactory yield, all attempts at diastereoselective epoxidation of $\mathbf{1 3}$ failed, regardless of the epoxidation methodology used. Various combinations of $N$-carbamate and $O$-ester/ether protecting groups were also assayed without success. In view of these results, we explored the use of cyclic sulfates as an alternative to epoxides, ${ }^{53,54}$ an approach that has been applied successfully in other iminosugar syntheses. ${ }^{55,56}$

The protection of the primary alcohol of $\mathbf{1 3}$ as a benzoate, followed by Sharpless asymmetric dihydroxylation of the intermediate ester (14), yielded a 90:10 mixture (HPLC) of diastereomeric diols, from which the major isomer 15 was isolated in 62\% yield (Scheme 2). Treatment of $\mathbf{1 5}$ with thionyl chloride gave a mixture of sulfites that was oxidized without further purification with $\mathrm{RuCl}_{3} / \mathrm{NaIO}_{4}$ to the corresponding cyclic sulfate 16, which was obtained as a single diasteroisomer in $80 \%$ overall yield (two steps). Treatment of 16 with $\mathrm{NaN}_{3}$ at $50^{\circ} \mathrm{C}$ gave an inseparable mixture of the azidoalcohols 17 and 18. Attempts to quantify the relative proportion of the two compounds at this stage by NMR or HPLC failed. The two azidoalcohols were hypothesized to be the result of the 
nuclephilic attack of the azide anion at $\mathrm{C} 2$ (glucoconfiguration) and $\mathrm{C} 3$ (altro-configuration) positions. Sequential treatment of this mixture with $\mathrm{NaOMe}$, in order to cleave the benzoate group, and $\mathrm{NaH}$ regenerated the 2-oxazolidinone ring, affording a 1:1 mixture of the bicyclic azidoalcohols 19 and 20 (Scheme 2). Although no selectivity was achieved during the cyclic sulfate opening reaction, both carbamates 19 and 20 were easily separated by column chromatography, which yielded crystalline compounds that could be analyzed by X-ray diffraction, $\uparrow$ thus confirming the proposed stereochemistry (Figure 2).

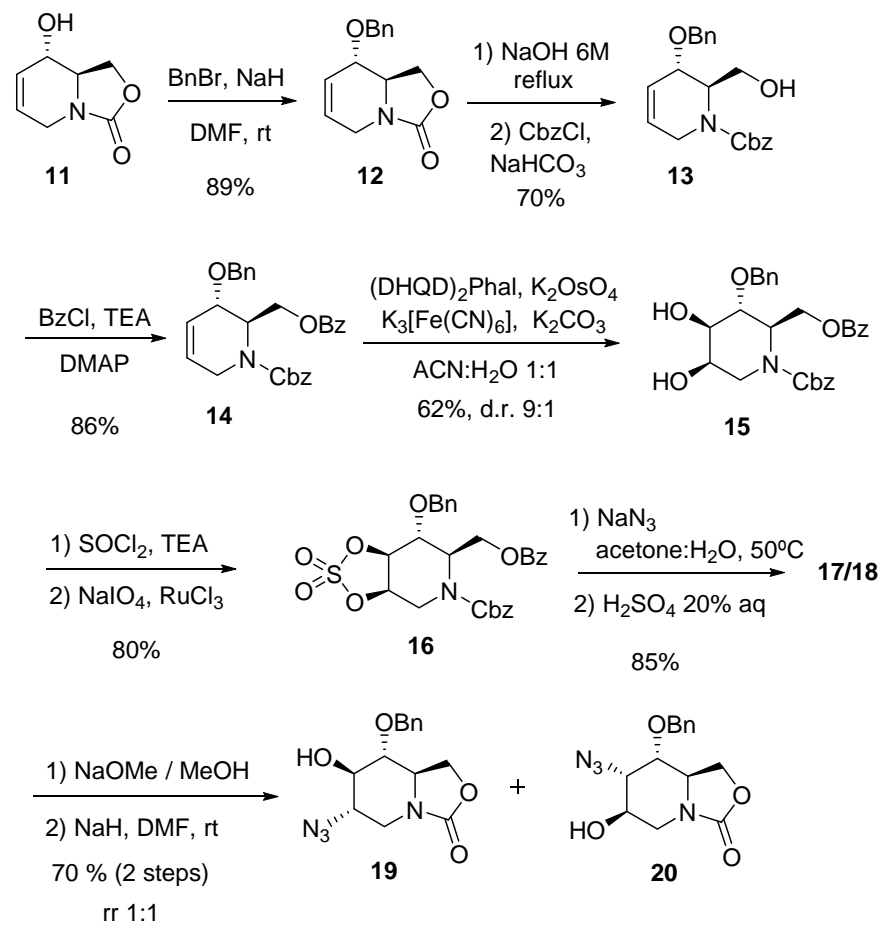

Scheme 2. Synthesis of the azido intermediates $\mathbf{1 9}$ and 20.

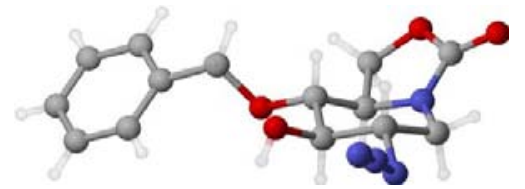

19

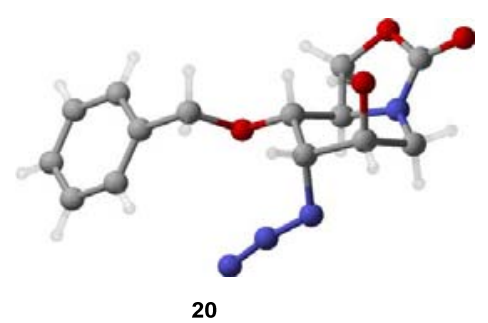

Figure 2. X-ray analysis of azido alcohols 19 and 20. $\dagger$

We envisaged that carbamate 19 would be an excellent precursor in the synthesis of DNJNAc (4) and ureidoDNJAc derivatives 10. The straightforward purification and facile separation of the two regioisomers encouraged us to look for a shorter route to synthetize the mixture of 19 and 20. Direct dihydroxylation of carbamate 12 using $\mathrm{K}_{2} \mathrm{OsO}_{4} \cdot 2 \mathrm{H}_{2} \mathrm{O} / \mathrm{NMO}$ afforded 21 in satisfactory yield and diastereoselectivity $(78 \%, 85: 15)$ (Scheme 3). Sharpless asymmetric dihydroxylation conditions increased both the yield and diasteroselectivity, affording diol 21 in 94\% yield and nearly complete diasteroselectivity, as observed by ${ }^{1} \mathrm{H}-\mathrm{NMR} .{ }^{17}$ The corresponding cyclic sulfate 22 was obtained in $80 \%$ yield by reaction of diol 21 with $\mathrm{SOCl}_{2} / \mathrm{TEA}$ followed by in situ oxidation with $\mathrm{NaIO}_{4} / \mathrm{RuCl}_{3}$, as in the previous case. Attempts to perform direct sulfation of $\mathbf{2 1}$ using $\mathrm{SO}_{2} \mathrm{Cl}_{2} / \mathrm{TEA}^{57}$ also afforded 22 but in lower yields.<smiles>O=C1CC[C@H]2[C@H](Oc3ccccc3)C=CCN12</smiles>

12

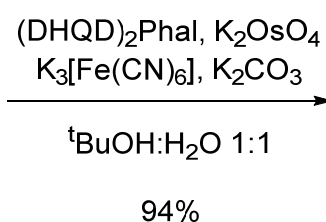

$94 \%$<smiles>O=C1OC[C@@H]2CN1C[C@@H](O)[C@@H]2O</smiles>

21

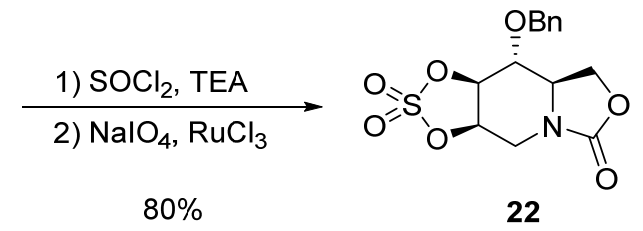<smiles>N[C@H]1CN2C(=O)OC[C@H]2[C@H](OCc2ccccc2)[C@H](O)[C@@H]1O</smiles>

Scheme 3. Synthesis of cyclic sulfate from 12 followed by ring-opening with sodium azide.

Regioselective ring-opening reactions of the key precursor 22 using $\mathrm{NaN}_{3}$ as the nucleophile were extensively studied and are summarized in Table 1 . We expected that the presence of the benzyl group at the $\mathrm{C} 4$ position would sterically hinder approaching of the azide anion nucleophile to $\mathrm{C} 3$, directing the attack to the $\mathrm{C} 2$ position (iminosugar numbering). The reaction did not take place in acetonitrile (entry 1) but proceeded in $N, N$ dimethylformamide (entries 2 and 3). Thus, treatment of sulfate 22 with sodium azide in DMF, followed by acidic hydrolysis (to cleave the intermediate residual sulfate), gave a 2:1 mixture of azidoalcohols in $70 \%$ yield (entry 2). However, increasing the temperature and the equivalents of $\mathrm{NaN}_{3}$, led to a dramatic decrease in yield and a total loss of selectivity (entry 3 ). In an attempt to improve the regioselectivity, the reaction was performed in acetone/water (entry 4 and 5), observing that fewer equivalents of azide allowed similar ratios. The use of lower temperatures $\left(40^{\circ} \mathrm{C}\right)$, even fewer equivalents of azide (1.2) and a longer reaction time (16 h), afforded higher yields, but also at the expenses of a total loss of 
regioselectivity (entry 6). Conversely, portion-wise addition of sodium azide increased the regioselectivity, but with a significant decrease in yield (entry 7). According to our objective of obtaining derivatives of $\mathbf{4}$, conditions of entry 5 were chosen for scaling up purposes.

Table 1. Optimization of the ring-opening reaction of sulfate 22 with sodium azide.

\begin{tabular}{ccccccc}
\hline Entry & Solvent & $\mathbf{T} /{ }^{\circ} \mathbf{C}$ & $\mathbf{t} / \mathbf{h}$ & $\begin{array}{c}\mathbf{N a N}_{3} \\
\mathbf{E q .}\end{array}$ & $\begin{array}{c}\text { Yield } \\
/ \%\end{array}$ & $\begin{array}{c}\mathbf{1 9} / \mathbf{2 0} \\
\mathbf{a}\end{array}$ \\
\hline 1 & ACN & 50 & 3 & 3 & - & - \\
2 & DMF & 50 & 3 & 4 & 70 & $1.9: 1$ \\
3 & DMF & 120 & 1 & 4 & 30 & $0.9: 1$ \\
4 & $\begin{array}{c}\text { Acetone/ } \\
\mathrm{H}_{2} \mathrm{O} 2: 1\end{array}$ & 50 & 3 & 3 & 68 & $1: 1$ \\
$5^{\mathrm{b}}$ & $\begin{array}{c}\text { Acetone/ } \\
\mathrm{H}_{2} \mathrm{O} 2: 1\end{array}$ & 50 & 6 & 2 & 62 & $1.8: 1$ \\
6 & $\begin{array}{c}\text { Acetone/ } \\
\mathrm{H}_{2} \mathrm{O} 2: 1\end{array}$ & 40 & 16 & 1.2 & 81 & $1: 1$ \\
$7^{\mathrm{c}}$ & $\begin{array}{c}\text { Acetone/ } \\
\mathrm{H}_{2} \mathrm{O} 2: 1\end{array}$ & 50 & 7 & 3 & 43 & $3: 1$ \\
\hline
\end{tabular}

${ }^{\mathrm{a}}$ Relation determined $\mathrm{w} / \mathrm{w}$ after purification

${ }^{b}$ The reaction was performed at multigram scale using these conditions.

${ }^{c}$ Portionwise addition of $\mathrm{NaN}_{3}$

The synthesis of DNJNAc 4 from azidoalcohol 19 is depicted in Scheme 4. Protection of the secondary alcohol by treatment with $\mathrm{BnBr} / \mathrm{NaH}$ gave 23 in $90 \%$ yield. Azide reduction with $\mathrm{H}_{2}$ and $\mathrm{Pd} / \mathrm{C}$ followed by in situ acetylation with $\mathrm{Ac}_{2} \mathrm{O} /$ pyridine afforded acetamide 24 in almost quantitative yield. This compound was then subjected to basic hydrolysis of the 2-oxazolidinone ring to give 25 in $92 \%$ yield. Final hydrogenolysis of the benzyl protecting groups gave DNJNAc (4) in 96\% yield. The spectroscopic data of this compound were consistent with previously reported data. ${ }^{18}$ The total synthesis of DNJNAc (4) from 11 was thus accomplished in 10 synthetic steps achieving a $23 \%$ overall yield.

Although some 3-acetamido iminosugar derivatives have been reported we could not find precedents of evaluation of their properties as glycosidase inhibitors. ${ }^{41,58,59} \mathrm{We}$ thus considered it of interest to apply the above synthetic sequence to azido alcohol $\mathbf{2 0}$, i.e. benzylation $(\rightarrow \mathbf{2 6})$, azide reduction and acetylation of the resulting amine $(\rightarrow 27)$, basic hydrolysis of the cyclic carbamate group $(\rightarrow \mathbf{2 8})$ and final hydrogenolysis of the benzyl protecting groups. In this manner, 3-acetamido-1,3dideoxyaltronojirimycin 29 was prepared in excellent overall yield (Scheme 5).<smiles>N[C@@H]1CN2C(=O)OC[C@H]2[C@H](O)[C@@H](O)[C@@H]1CC(=O)NBr</smiles>

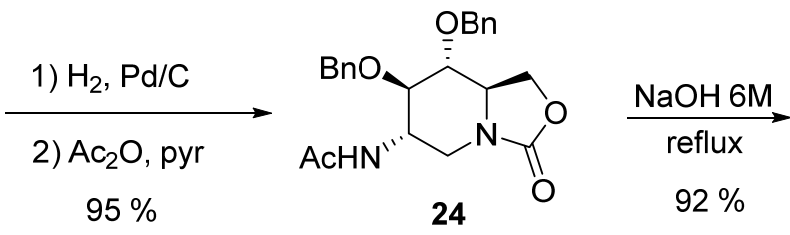

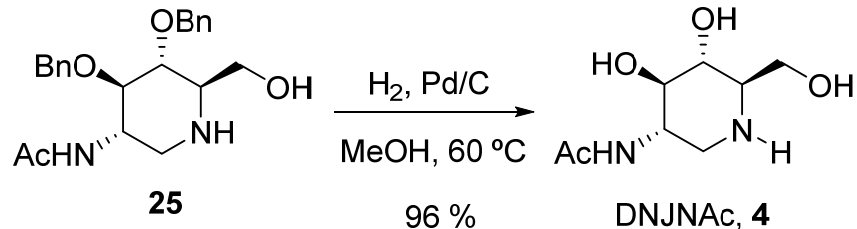

Scheme 4. Synthesis of DNJNAc (4).<smiles>N[C@H]1[C@@H](O)CN2C(=O)OC[C@H]2[C@H]1OCc1ccccc1</smiles>

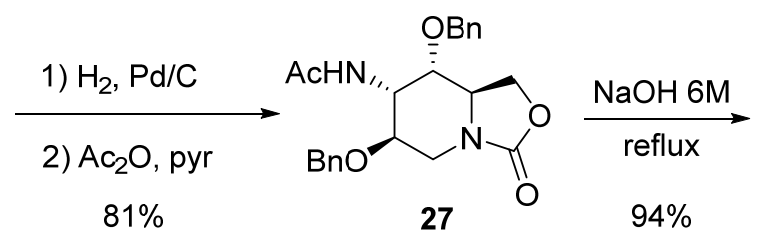

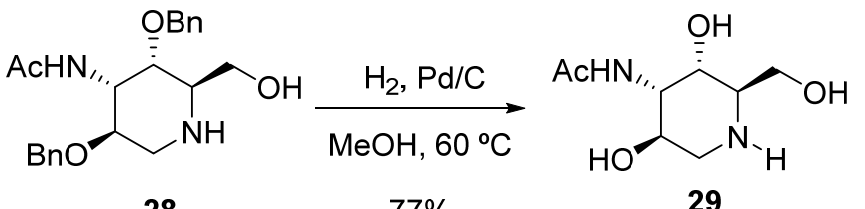
Scheme 5. Synthesis of 3-acetamido-1,3dideoxyaltronojirimycin (29).

It has been described that modifications of the acetamide moiety in DNJNAc lead to a dramatic decrease in the inhibitory activity against hexosaminidases, ${ }^{40}$ while modifications at the endocyclic amine are well tolerated. Indeed, the incorporation of hydrophobic $N$-alkyl substituents has been previously investigated, ${ }^{18,60}$ and found to lead to an improvement of the inhibitory potency which is consistent with the presence of a hydrophobic pocket in the vicinity of the active site of the enzyme. ${ }^{61}$ All DNJNAc analogs reported to date keep the basic character of the piperidine glycone-like skeleton, generally considered a favorable structural feature to promote strong binding to the enzyme. However, it has been demonstrated that higher glycosidase affinities and, especially, improved 
selectivities can be achieved by the interplay of neutral glycone-type cores and substituents that provide additional non-glycone interactions. ${ }^{62,63}$ Transmuting the endocyclic $\mathrm{sp}^{3}$-amine nitrogen into a $\mathrm{sp}^{2}$-hybridized pseudoamide functionality by introduction of amide, urea, thiourea or guanidinium moieties has proven particularly successful in this respect. ${ }^{64-68}$ For instance, $N$-( $N$ '-butylaminocarbamoyl)-1-deoxynojirimycin, the urea analog of the marketed drug Zavesca, was found to be a very selective inhibitor of bovine liver $\beta$ galactosidase. ${ }^{67}$ The $\mathrm{sp}^{2}$-hybridized character is also observed in some natural products such as kifunensine, a potent inhibitor of class I $\alpha$-mannosidase. ${ }^{69,70}$ To check this strategy for the particular case of hexosaminidases, we synthesized a series of ureido-DNJNAc derivatives (10). In addition to a much lower basic character at the endocyclic nitrogen, conversion of an amine into a urea offers flexibility in the choice of substituents, which can be taken advantage of to optimize the inhibitory capacity and the pharmacokinetic behavior.

The oxazolidinone ring of azido alcohol 19 was hydrolyzed under the usual conditions and the endocyclic amine was protected in situ using $\mathrm{Boc}_{2} \mathrm{O} / \mathrm{NaHCO}_{3}$ to give azidoalcohol 30. Concomitant azide reduction and cleavage of the benzyl group were accomplished by hydrogenation in methanol/acetic acid. The resulting vicaminoalcohol was acetylated without further purification by treatment with $\mathrm{Ac}_{2} \mathrm{O}$ in pyridine to afford acetamide 31 in $83 \%$ yield ( 2 steps). Next, the $N$-Boc group was selectively cleaved using TFA, and the resulting cyclic amine was reacted in situ with $n$-butyl, $n$-octyl, phenyl or benzyl isocyanate in the presence of triethylamine (TEA) to give the corresponding urea adducts 32a-d in 70-85\% yield. Final deacetylation using a saturated solution of ammonia in $\mathrm{MeOH}$ gave the target ureido-DNJNAc derivatives 10a-d (Scheme 6).

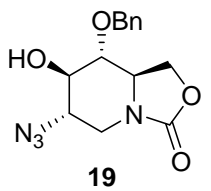

19

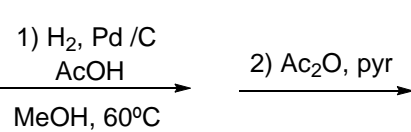

$83 \%$

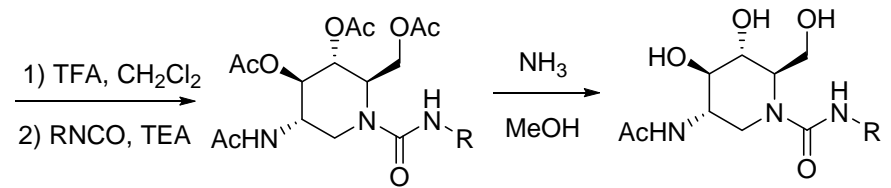

$\begin{array}{lllll}81 \% & \text { 32a } & R=n-B u & 61 \% & \text { 10a } R=n-B u \\ 85 \% & \text { 32b } & R=n-O c t & 75 \% & \text { 10b } R=n-O c t \\ 80 \% & \text { 32c } & R=P h & 58 \% & \text { 10c } R=P h \\ 70 \% & \text { 32d } & R=B n & 76 \% & \text { 10d } R=B n\end{array}$

Scheme 6. Synthesis of ureido-DNJNAc derivatives 10a-d

Evaluation of the glycosidase inhibitory activity of the DNJNAc regioisomer $\mathbf{2 9}$ and the ureido-DNJNAc derivatives 10a-d, in comparison with the parent acetamido iminosugar 4, confirmed their total selectivity towards hexosaminidases among a panel that included the following: $\beta$-glucosidases (almonds and bovine liver), $\alpha$-glucosidase (yeast), $\alpha$-mannosidase (jack bean), $\beta$ mannosidase (Helix pomatia), trehalase (pig kidney), amyloglucosidase (Aspergillus niger), $\alpha$-rhamnosidase (naringinasa; Penicillium decumbens), $\alpha$-galactosidase (green coffee), $\beta$-galactosidase ( $E$. coli), and isomaltase (yeast). Compound 29 was a much weaker inhibitor than DNJNAc, confirming that even when hexosaminidases are relatively promiscuous regarding the configurational pattern of iminosugar-type ligands, the location of the acetamido group next to the anomeric position is critical to ensure strong enzyme binding. Gratifyingly, all ureido-DNJNAc derivatives 10a-d behaved as $\mu \mathrm{M}$ inhibitors of the three hexosaminidases assayed in this work, namely those from human placenta, bovine kidney, and jack beans. $N$ '-alkyl substituents ( $n$-butyl, $n$-octyl or benzyl; 10a, 10b and 10d) led to a slight decrease in the inhibitory potency as compared with $\mathbf{4}$, with inhibition constant $\left(K_{\mathrm{i}}\right)$ values in the $56-20 \mu \mathrm{M}$ range for the human enzyme. The $N^{\prime}$-phenyl derivative 10c was an about one order of magnitude stronger inhibitor of the hexosaminidases as compred with the $N$ 'alkyl counterparts. Notably, the inhibition potency against the human enzyme surpassed that of $\mathbf{4}$ by over 3 -fold. This result is remarkable considering the much lower basicity of 10c as compared with 4 . The data suggest the involvement of the urea NH proton in hydrogen bonding in the complex of ureido-DNJNAc with the hexosaminidases, compensating the electrostatic interactions operating in the case of the basic iminosugar, as previously demonstrated for other $\mathrm{sp}^{2}$ iminosugar:glycosidase complexes. ${ }^{71}$ The higher hydrogen bond donor capability of arylureas as compared with alkylureas, due to the electron withdrawing character of the aromatic ring, is consistent with the observed activity trend. Most interestingly, the amphiphilic character of the compounds is expected to confer better drug-like properties. Altogether, the results reported herein are promising for the further development of therapeutic agents for $\beta$-GlcNAcaserelated diseases.

\section{Conclusions}

Here we have described a new stereoselective synthesis of 2-acetamido-1,2-dideoxynojirimycin (DNJNAc), the iminosugar analog of $N$-acetylglucosamine, with high overall yield. The strategy is based on the stereoselective ring-opening of cyclic sulfates derived from the key intermediate 11, which was conveniently prepared by a multigram procedure based on Sharpless epoxidation. This novel procedure gave access to the advanced 
intermediate 19 which provided us with the necessary protecting group arrangement to synthesize $\mathrm{sp}^{2}-$ iminosugar conjugates through derivatization of the endocyclic amine by reaction with isocyanates. These new ureido-DNJNAc derivatives are the first neutral inhibitors of hexosaminidases described to date. These compounds were potent inhibitors of $\beta$-GlcNAcase and, given their amphiphlic character, they are expected to show acceptable drug-like properties.

Table 2. Inhibition constants $\left(K_{\mathrm{i}}, \mu \mathrm{M}\right)^{\mathrm{a}}$ against commercial $\beta$ - $N$-acetylglucosaminidases 10a-d and 29 determined from thee slope of Lineweaver-Burk plots and double reciprocal analysis compared with previously reported values for DNJNAc (4). ${ }^{18}$

\begin{tabular}{|c|c|c|c|c|c|c|}
\hline \multirow[b]{2}{*}{ Enzyme origin } & \multirow{2}{*}{4} & \multirow{2}{*}{29} & \multicolumn{4}{|c|}{ AcHN" $_{O}^{\mathrm{OH}}$} \\
\hline & & & $\begin{array}{c}10 \mathrm{a} \\
\mathrm{R}=n-\mathrm{Bu}\end{array}$ & $\begin{array}{c}10 \mathrm{~b} \\
\mathrm{R}=n-\mathrm{Oct}\end{array}$ & $\begin{array}{c}10 c \\
R=P h\end{array}$ & $\begin{array}{c}10 d \\
R=B n\end{array}$ \\
\hline Human placenta & $7.0 \pm 0.3$ & $427 \pm 20$ & $56 \pm 5$ & $33 \pm 3$ & $2.1 \pm 0.1$ & $20 \pm 1$ \\
\hline Bovine kidney & $7.4 \pm 0.3$ & $524 \pm 40$ & $138 \pm 10$ & $82 \pm 5$ & $4.1 \pm 0.2$ & $24 \pm 2$ \\
\hline Jack Bean & $2.9 \pm 0.2$ & $130 \pm 10$ & $26 \pm 3$ & $19 \pm 2$ & $1.1 \pm 0.1$ & $10 \pm 1$ \\
\hline
\end{tabular}

${ }^{a}$ Inhibition was competitive in all cases.

\section{Experimental}

\section{General}

All commercial reagents were used without further purification. Non-aqueous reactions were performed out under nitrogen atmosphere. Dry tetrahydrofuran, dichloromethane, and diethyl ether were obtained using a Solvent Purification System (SPS). Other solvents were used with no further purification. All reactions were monitored by TLC analysis using Merck 60 F254 silica gel on aluminum sheets. Silica gel chromatography was performed by using $35-70 \mathrm{~mm}$ silica or an automated chromatography system. NMR spectra were recorded at room temperature on a $400 \mathrm{MHz}$ instrument. ${ }^{1} \mathrm{H}$ and ${ }^{13} \mathrm{C}-\mathrm{NMR}$ spectra were referenced to the residual peaks of the deuterated solvent. The following abbreviations were used to define the multiplicities: s, singlet; d, doublet; $t$, triplet; q, quadruplet; m, multiplet; and br, broad signal. The chemical shifts $(\delta)$ are expressed in ppm and the coupling constants $(J)$, in Hertz $(\mathrm{Hz})$. IR spectra were recorded either by preparing a $\mathrm{KBr}$ pastille or by depositing a film of the product on a $\mathrm{NaCl}$ window. Absorptions are given in wavenumbers $\left(\mathrm{cm}^{-1}\right)$. Melting points were recorded in a Büchi M-540 apparatus without recrystallization of the final solids. Optical rotations were measured at room temperature $\left(25^{\circ} \mathrm{C}\right)$. Concentration is expressed in $\mathrm{g} / 100 \mathrm{~mL}$ and solvent is expressed for each case in brackets. The cell was $10 \mathrm{~cm}$ long and had $1 \mathrm{~mL}$ of capacity. Measuring $\lambda$ was $589 \mathrm{~nm}$, which corresponds to a sodium lamp. High Resolution Mass Spectrometry were conducted using nanoelectrospray technique..

Preparation of $\mathbf{1 1}^{47}, \mathbf{1 2} \mathbf{2}^{48}$ and $\mathbf{2 1}^{17,48}$ was done following literature procedures. Starting material 11 was $99 \%$ ee.

Syntheses and characterizations of compounds in Scheme 5, and derivatives 32b-d and 10b-d can be found in the supporting information.
(2R,3S)-3-Benzyloxy- $N$-benzyloxycarbonyl-2hydroxymethyl-3,6-dihydropyridine (13)

$\mathrm{NaOH} 6 \mathrm{M}(2.86 \mathrm{~mL}, 17.10 \mathrm{mmol})$ was added to a solution of 12 (421 mg, $1.71 \mathrm{mmol})$ in $\mathrm{MeOH}: \mathrm{H}_{2} \mathrm{O}$ 9:1 (18 mL), and the reaction was heated at reflux for $20 \mathrm{~h}$. Solvents were removed at low pressure. The resulting white solid was dissolved in THF $(30 \mathrm{~mL})$ and $\mathrm{H}_{2} \mathrm{O}(3 \mathrm{~mL})$ and cooled at $0{ }^{\circ} \mathrm{C} . \mathrm{NaHCO}_{3}(432 \mathrm{mg}$, $5.14 \mathrm{mmol})$ and $\mathrm{CbzCl}(0.39 \mathrm{~mL}, 2.57 \mathrm{mmol})$ were added and the reaction was stirred at $0{ }^{\circ} \mathrm{C}$ for $4 \mathrm{~h} . \mathrm{H}_{2} \mathrm{O}(10 \mathrm{~mL})$ was then added, and the crude product was extracted with EtOAc ( $3 \times 15$ $\mathrm{mL}$ ), dried over $\mathrm{MgSO}_{4}$ and purified on $\mathrm{SiO}_{2}$ using hexane/EtOAc to yield $13(427 \mathrm{mg}, 70 \%)$ as a colorless oil. $[\alpha]^{20} \mathrm{D}=+50.3\left(\mathrm{c}=1.05, \mathrm{CHCl}_{3}\right) .{ }^{1} \mathrm{H}-\mathrm{NMR}\left(400 \mathrm{MHz}, \mathrm{CDCl}_{3}\right.$, $\delta / \mathrm{ppm}): 7.32-7.25(\mathrm{~m}, 10 \mathrm{H}), 5.91(\mathrm{~m}, 2 \mathrm{H}), 5.18(\mathrm{~m}, 2 \mathrm{H}), 4.78$ $(\mathrm{m}, 2 \mathrm{H}), 4.52(\mathrm{~m}, 2 \mathrm{H}), 4.40(\mathrm{~m}, 2 \mathrm{H}), 3.96(\mathrm{~m}, 1 \mathrm{H}), 3.55(\mathrm{~m}$, $3 \mathrm{H}) .{ }^{13} \mathrm{C}-\mathrm{NMR}\left(100 \mathrm{MHz}, \mathrm{CDCl}_{3}, \delta / \mathrm{ppm}\right): 157.2$ (CO), 138.1 (C), $137.1(\mathrm{C}), 128.5(\mathrm{CH}), 128.4(\mathrm{CH}), 127.9(\mathrm{CH}), 127.8$ $(\mathrm{CH}), 127.6(\mathrm{CH}), 122.8(\mathrm{CH}), 70.4\left(\mathrm{CH}_{2}\right), 69.3(\mathrm{CH}), 67.4$ $\left(\mathrm{CH}_{2}\right), 61.5(\mathrm{CH}), 54.6\left(\mathrm{CH}_{2}\right), 40.9\left(\mathrm{CH}_{2}\right)$. IR (film, $v_{\max } / \mathrm{cm}^{-}$ $\left.{ }^{1}\right)$ : 3442, 1700, 1412, 1344, 1236. HRMS (ES): calcd. for $\mathrm{C}_{21} \mathrm{H}_{25} \mathrm{NO}_{4}: 354.1705$ found 354.1703 .

\section{(2R,3S)-2-Benzoyloxymethyl-3-benzyloxy- $N$ -}

\section{benzyloxycarbonyl-3,6-dihydropyridine (14)}

DMAP $(10 \mathrm{mg}, 0.08 \mathrm{mmol})$, TEA $(0.29 \mathrm{~mL}, 2.04 \mathrm{mmol})$, and benzoyl chloride $(0.19 \mathrm{~mL}, 1.63 \mathrm{mmol})$ were added to a solution of $13(288 \mathrm{mg}, 0.82 \mathrm{mmol})$ in $\mathrm{CH}_{2} \mathrm{Cl}_{2}(10 \mathrm{~mL})$ and the reaction was stirred at r.t. until no starting material was observed by TLC. Solvent was removed under low pressure and the crude was purified by chromatography on silica gel using hexane/ethyl acetate to give $14(316 \mathrm{mg}, 86 \%)$ as a colorless oil. $[\alpha]^{20} \mathrm{D}=+15.6\left(\mathrm{c}=1.05, \mathrm{CHCl}_{3}\right) .{ }^{1} \mathrm{H}-\mathrm{NMR}(400 \mathrm{MHz}$, $\left.\mathrm{CDCl}_{3}, 55^{\circ} \mathrm{C}, \delta / \mathrm{ppm}\right): 7.93(\mathrm{~d}, J=7.5 \mathrm{~Hz}, 2 \mathrm{H}), 7.55(\mathrm{tt}, J=$ $7.5,1.5 \mathrm{~Hz}, 1 \mathrm{H}), 7.39(\mathrm{tt}, J=7.5,1.5 \mathrm{~Hz}, 2 \mathrm{H}), 7.33-7.17(\mathrm{~m}$, $10 \mathrm{H}), 6.00(\mathrm{br}, 1 \mathrm{H}), 5.94(\mathrm{~m}, 1 \mathrm{H}), 5.17(\mathrm{~d}, J=12.5 \mathrm{~Hz}, 1 \mathrm{H})$, 5.02 (br, $2 \mathrm{H}), 4.65(\mathrm{br}, 1 \mathrm{H}), 4.54(\mathrm{~m}, 1 \mathrm{H}), 4.46(\mathrm{~m}, J=14.0$, 
$8.0 \mathrm{~Hz}, 1 \mathrm{H}), 4.26(\mathrm{~s}, 2 \mathrm{H}), 3.95(\mathrm{~s}, 1 \mathrm{H}), 3.71(\mathrm{~d}, J=19.0 \mathrm{~Hz}$, 1H). ${ }^{13} \mathrm{C}-\mathrm{NMR}\left(100 \mathrm{MHz}, \mathrm{CDCl}_{3}, \delta / \mathrm{ppm}\right): 166.1(\mathrm{CO}), 166.0^{*}$ (CO), $156.0(\mathrm{CO}), 155.8^{*}(\mathrm{CO}), 137.8(\mathrm{C}), 136.4(\mathrm{C}), 133.1$ (C), $133.1^{*}(\mathrm{C}), 129.6(\mathrm{CH}), 129.6(\mathrm{CH}), 129.1(\mathrm{CH}), 128.4$ $(\mathrm{CH}), 128.0(\mathrm{CH}), 127.9(\mathrm{CH}), 127.9(\mathrm{CH}), 127.8(\mathrm{CH}), 127.7$ $(\mathrm{CH}), 127.6(\mathrm{CH}), 127.5(\mathrm{CH}), 122.6(\mathrm{CH}), 122.3^{*}(\mathrm{CH}), 70.4$ $\left(\mathrm{CH}_{2}\right), 70.3 *\left(\mathrm{CH}_{2}\right), 69.3(\mathrm{CH}), 69.1 *(\mathrm{CH}), 67.3\left(\mathrm{CH}_{2}\right), 67.2 *$ $\left(\mathrm{CH}_{2}\right), 62.5\left(\mathrm{CH}_{2}\right), 62.2 *\left(\mathrm{CH}_{2}\right), 52.0(\mathrm{CH}), 51.0 *(\mathrm{CH}), 40.9$ $\left(\mathrm{CH}_{2}\right), 40.5 *\left(\mathrm{CH}_{2}\right) *$ Rotamers. IR (film, $\left.v_{\max } / \mathrm{cm}^{-1}\right): 3039$, 2943, 1720, 1702, 1421, 1414, 1272, 1068. HRMS (ES): calcd. for $\mathrm{C}_{28} \mathrm{H}_{27} \mathrm{NO}_{5} \mathrm{Na}$ : 480.1781 , found 480.1781 .

\section{6-O-Benzoyl-4-O-benzyl-5- $\mathrm{N}$-benzyloxycarbonyl-1-}

deoxymannojirimycin (15)

(DHQD) ${ }_{2} \mathrm{Phal}$ (46 mg, $0.06 \mathrm{mmol}$ ), $\mathrm{K}_{2} \mathrm{OsO}_{4}$ (10 mg, 0.03 $\mathrm{mmol}), \mathrm{K}_{2} \mathrm{CO}_{3}(288 \mathrm{mg}, 2.08 \mathrm{mmol})$ and $\mathrm{K}_{3}\left[\mathrm{Fe}(\mathrm{CN})_{6}\right](693 \mathrm{~g}$, $2.08 \mathrm{mmol})$ were dissolved in $\mathrm{ACN}: \mathrm{H}_{2} \mathrm{O} 1: 1(6 \mathrm{~mL})$. The reaction was cooled to $0{ }^{\circ} \mathrm{C}$ and $\mathrm{CH}_{3} \mathrm{SO}_{2} \mathrm{NH}_{2}(69 \mathrm{mg}, 0.69$ mmol) was then added. After 10 min, a solution of $14(318 \mathrm{mg}$, $0.69 \mathrm{mmol})$ in $\mathrm{ACN}: \mathrm{H}_{2} \mathrm{O} 1: 1(6 \mathrm{~mL})$ was added and the mixture was left to warm to r.t. and stirred until no starting material was observed by TLC. The reaction was treated with $\mathrm{Na}_{2} \mathrm{SO}_{3}(400$ $\mathrm{mg}$ ) and stirred for $60 \mathrm{~min}$. It was then extracted with EtOAc $(3 \mathrm{x} 10 \mathrm{~mL})$ and the organic phase was washed with brine $(1 \mathrm{x}$ $10 \mathrm{~mL}$ ), dried with $\mathrm{MgSO}_{4}$, and purified by chromatography on silica gel using hexane:EtOAc to give $15(212 \mathrm{mg}, 62 \%)$ as one diastereomer as a sticky white foam. $[\alpha]^{20} \mathrm{D}=-20.0(\mathrm{c}=0.76$, $\mathrm{CHCl}_{3}$ ). ${ }^{1} \mathrm{H}-\mathrm{NMR}\left(400 \mathrm{MHz}, \mathrm{CDCl}_{3}, \delta / \mathrm{ppm}\right): 7.93$ (d, $J=7.5$ $\mathrm{Hz}, 2 \mathrm{H}), 7.54(\mathrm{t}, J=7.5 \mathrm{~Hz}, 1 \mathrm{H}), 7.38(\mathrm{t}, J=7.5 \mathrm{~Hz}, 2 \mathrm{H}), 7.32$ - $7.11(\mathrm{~m}, 10 \mathrm{H}), 5.07$ (d, $J=11.5 \mathrm{~Hz}, 1 \mathrm{H}), 4.94(\mathrm{br}, 1 \mathrm{H}), 4.86$ (br, 1H), $4.76(\mathrm{dd}, J=11.5,9.5 \mathrm{~Hz}, 1 \mathrm{H}), 4.59(\mathrm{br}, 1 \mathrm{H}), 4.47$ (d, $, J=12.0 \mathrm{~Hz}, 1 \mathrm{H}), 4.41(\mathrm{dd},, J=12.0,5.0 \mathrm{~Hz}, 1 \mathrm{H}), 4.17(\mathrm{br}$ $1 \mathrm{H}), 4.07(\mathrm{~s}, 1 \mathrm{H}), 4.03(\mathrm{br}, 1 \mathrm{H}), 3.75(\mathrm{t}, J=2.5 \mathrm{~Hz}, 1 \mathrm{H}), 3.14$ $(\mathrm{dd}, J=13.0,11.0 \mathrm{~Hz}, 1 \mathrm{H}), 2.95(\mathrm{br}, 1 \mathrm{H}) .{ }^{13} \mathrm{C}-\mathrm{NMR}(100 \mathrm{MHz}$, $\left.\mathrm{CDCl}_{3}, \delta / \mathrm{ppm}\right): 166.4(\mathrm{CO}), 156.2(\mathrm{CO}), 137.4(\mathrm{C}), 136.2(\mathrm{C})$ $133.0(\mathrm{C}), 129.8(\mathrm{CH}), 129.6(\mathrm{CH}), 128.4(\mathrm{CH}), 128.4(\mathrm{CH})$, $128.3(\mathrm{CH}), 128.2(\mathrm{CH}), 127.9(\mathrm{CH}), 127.8(\mathrm{CH}), 127.6(\mathrm{CH})$, $75.5(\mathrm{CH}), 71.3\left(\mathrm{CH}_{2}\right), 69.5(\mathrm{CH}), 67.5\left(\mathrm{CH}_{2}\right), 64.7(\mathrm{CH}), 61.7$ $\left(\mathrm{CH}_{2}\right), 52.3(\mathrm{CH}), 39.4\left(\mathrm{CH}_{2}\right)$. IR (film, $\left.v_{\max } / \mathrm{cm}^{-1}\right)$ : 3428 , 2911, 1719, 1699, 1450, 1429, 1274, 1068. HRMS (ES): calcd. for $\mathrm{C}_{28} \mathrm{H}_{30} \mathrm{NO}_{7}$ : 492.2017, found 492.2024.

\section{6-O-Benzoyl-4-O-benzyl-5- $\mathrm{N}$-benzyloxycarbonyl-2,3-O-}

\section{(cyclic sulfate)-1-deoxymannojirimycin (16)}

TEA $(0.25 \mathrm{~mL}, 1.80 \mathrm{mmol})$ was added to a solution of $\mathbf{1 5}(211$ $\mathrm{mg}, 0.43 \mathrm{mmol})$ in THF $(12 \mathrm{~mL})$ cooled at $0^{\circ} \mathrm{C}$ and $\mathrm{SOCl}_{2}(100$ $\mu \mathrm{L}, 1.54 \mathrm{mmol})$ was then added dropwise. The reaction was stirred at $0^{\circ} \mathrm{C}$ until no starting material was observed by TLC $\mathrm{H}_{2} \mathrm{O}(5 \mathrm{~mL})$ was then added and the crude was extracted with $\mathrm{CH}_{2} \mathrm{Cl}_{2}(3 \times 5 \mathrm{~mL})$ and dried over $\mathrm{MgSO}_{4}$. The solvent was removed under low pressure and the obtained oil was dissolved in $\mathrm{ACN}: \mathrm{CCl}_{4}: \mathrm{H}_{2} \mathrm{O}$ 1:1:1 mixture $(7.5 \mathrm{~mL})$ and cooled at $0^{\circ} \mathrm{C}$ $\mathrm{RuCl}_{3}(9 \mathrm{mg}, 0.04 \mathrm{mmol})$ and $\mathrm{NaIO}_{4}(184 \mathrm{mg}, 0.86 \mathrm{mmol})$ were added and the reaction was allowed to stir at $0^{\circ} \mathrm{C}$ until no starting material was observed by TLC. $\mathrm{H}_{2} \mathrm{O}(5 \mathrm{~mL})$ and $\mathrm{Et}_{2} \mathrm{O}(5$ $\mathrm{mL}$ ) were added, and the reaction was stirred $10 \mathrm{~min}$. The organic phase was separated and washed with $\mathrm{NaHCO}_{3}(1 \mathrm{x}$ $5 \mathrm{~mL})$ and brine $(1 \times 5 \mathrm{~mL})$, and dried with $\mathrm{MgSO}_{4}$. The solvent was removed under low pressure. Purification by chromatography on silica gel using hexane/ethyl acetate gave $16(190 \mathrm{mg}, 75 \%)$ as one diastereomer as colorless oil. $[\alpha]^{20} \mathrm{D}=$ $-16.3\left(\mathrm{c}=0.63, \mathrm{CHCl}_{3}\right) .{ }^{1} \mathrm{H}-\mathrm{NMR}\left(400 \mathrm{MHz}, \mathrm{CDCl}_{3}, \delta / \mathrm{ppm}\right)$ : $7.87(\mathrm{dd}, J=7.5,1.0 \mathrm{~Hz}, 2 \mathrm{H}), 7.58(\mathrm{tt}, J=7.5,1.0 \mathrm{~Hz}, 1 \mathrm{H})$, $7.44(\mathrm{t}, J=7.5 \mathrm{~Hz}, 2 \mathrm{H}), 7.34-7.24(\mathrm{~m}, 9 \mathrm{H}), 7.19(\mathrm{tt}, J=6.0$, $1.5 \mathrm{~Hz}, 1 \mathrm{H}), 5.14(\mathrm{~d}, J=11.5 \mathrm{~Hz}, 1 \mathrm{H}), 5.08(\mathrm{br}, 2 \mathrm{H}), 5.02(\mathrm{t}, J$ $=7.0 \mathrm{~Hz}, 1 \mathrm{H}), 4.79(\mathrm{~d}, J=11.5 \mathrm{~Hz}, 1 \mathrm{H}), 4.65(\mathrm{~m}, 2 \mathrm{H}), 4.55(\mathrm{~d}$,
$J=11.0 \mathrm{~Hz}, 1 \mathrm{H}), 4.40(\mathrm{br}, 1 \mathrm{H}), 4.32(\mathrm{t}, J=7.0 \mathrm{~Hz}, 1 \mathrm{H}), 3.41$ (br, $1 \mathrm{H}) .{ }^{13} \mathrm{C}-\mathrm{NMR}\left(100 \mathrm{MHz}, \mathrm{CDCl}_{3}, \delta / \mathrm{ppm}\right): 165.8(\mathrm{CO})$, $154.9(\mathrm{CO}), 135.9(\mathrm{C}), 135.3(\mathrm{C}), 133.4(\mathrm{CH}), 129.6(\mathrm{CH})$ $129.2(\mathrm{C}), 128.7(\mathrm{CH}), 128.6(\mathrm{CH}), 128.5(\mathrm{CH}), 128.4(\mathrm{CH})$, $128.2(\mathrm{CH}), 81.7(\mathrm{CH}), 74.5(\mathrm{CH}), 73.7\left(\mathrm{CH}_{2}\right), 70.8(\mathrm{CH}), 68.4$ $\left(\mathrm{CH}_{2}\right), 61.7\left(\mathrm{CH}_{2}\right), 53.9(\mathrm{CH}), 40.1\left(\mathrm{CH}_{2}\right)$. IR (film, $v_{\max } / \mathrm{cm}^{-}$ $\left.{ }^{1}\right): 1714,1397,1271,1212,1112,1098,982,712$, 699. HRMS (ES): calcd. for $\mathrm{C}_{28} \mathrm{H}_{31} \mathrm{~N}_{2} \mathrm{O}_{9} \mathrm{~S}: 571.1745$, found 571.1747 .

4-O-Benzyl-2,3-O-(cyclic sulfate)-5N,6O-(cyclic carbamate)1-deoxymannojirimycin (22)

Diol 21 (3.18 g, $11.38 \mathrm{mmol})$ was dissolved in THF $(120 \mathrm{~mL})$ and cooled to $0^{\circ} \mathrm{C}$. Triethyl amine $(6.66 \mathrm{~mL}, 47.81 \mathrm{mmol})$ was added and after $10 \mathrm{~min} \mathrm{SOCl}_{2}(2.5 \mathrm{~mL}, 38.72 \mathrm{mmol})$ was added dropwise. The reaction was stirred at $0^{\circ} \mathrm{C}$ for $1 \mathrm{~h}$, then treated with water $(9 \mathrm{~mL})$ and extracted with $\mathrm{CH}_{2} \mathrm{Cl}_{2}(3 \times 15 \mathrm{~mL})$. The solvent was removed under reduced pressure to give an orange

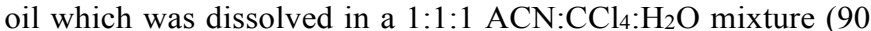
$\mathrm{mL})$ and cooled to $0^{\circ} \mathrm{C}$. $\mathrm{RuCl}_{3}(35 \mathrm{mg}, 0.17 \mathrm{mmol})$ and $\mathrm{NaIO}_{4}$ $(4.87 \mathrm{~g}, 22.77 \mathrm{mmol})$ were added and the reaction was stirred at $0^{\circ} \mathrm{C}$ vigorously for $4 \mathrm{~h}$. Treatment consisted of the addition of $\mathrm{Et}_{2} \mathrm{O}(20 \mathrm{~mL})$ and $\mathrm{H}_{2} \mathrm{O}(20 \mathrm{~mL})$. The organic phase was washed with $\mathrm{NaHCO}_{3}(1 \times 20 \mathrm{~mL})$ and brine $(1 \times 10 \mathrm{~mL})$, dried over $\mathrm{MgSO}_{4}$, and purified by chromatography on silica gel using hexane/ethyl acetate and increasing the polarity ratio to give $\mathbf{2 2}$ as a white foam $(3.12 \mathrm{~g}, 80 \%)$. $[\alpha]^{20} \mathrm{D}=+47.6\left(\mathrm{c}=0.5, \mathrm{CHCl}_{3}\right)$. Mp: $157-158{ }^{\circ} \mathrm{C} .{ }^{1} \mathrm{H}-\mathrm{NMR}\left(400 \mathrm{MHz}, \mathrm{CDCl}_{3}, \delta / \mathrm{ppm}\right): 7.45-$ $7.31(\mathrm{~m}, 5 \mathrm{H}), 5.18(\mathrm{~m}, 1 \mathrm{H}), 4.95(\mathrm{dd}, J=8.0,4.5 \mathrm{~Hz}, 1 \mathrm{H}), 4.91$ $(\mathrm{d}, J=11.5 \mathrm{~Hz}, 1 \mathrm{H}), 4.65(\mathrm{~d}, J=11.5 \mathrm{~Hz}, 1 \mathrm{H}), 4.45(\mathrm{~d}, J=$ $16.0 \mathrm{~Hz}, 1 \mathrm{H}), 4.36(\mathrm{dd}, J=9.5,8.0 \mathrm{~Hz}, 1 \mathrm{H}), 3.98(\mathrm{dd}, J=9.5$, $8.0 \mathrm{~Hz}, 1 \mathrm{H}), 3.84(\mathrm{dd}, J=9.5,4.5 \mathrm{~Hz}, 1 \mathrm{H}), 3.59-3.50(\mathrm{~m}$, $1 \mathrm{H}), 3.36(\mathrm{dd}, J=16.0,3.0 \mathrm{~Hz}, 1 \mathrm{H}) .{ }^{13} \mathrm{C}-\mathrm{NMR}(100 \mathrm{MHz}$, $\left.\mathrm{CDCl}_{3}, \delta / \mathrm{ppm}\right): 156.1(\mathrm{CO}), 136.1(\mathrm{C}), 128.9(\mathrm{CH}), 128.8$ $(\mathrm{CH}), 128.6(\mathrm{CH}), 86.7(\mathrm{CH}), 79.1(\mathrm{CH}), 75.2(\mathrm{CH}), 74.4$ $\left(\mathrm{CH}_{2}\right), 65.4\left(\mathrm{CH}_{2}\right), 54.3(\mathrm{CH}), 39.9\left(\mathrm{CH}_{2}\right)$. IR (film, $v_{\max } / \mathrm{cm}^{-}$ $\left.{ }^{1}\right): 2902,1755,1439,1389,1214,1070,1014$. HRMS (ES): calcd. for $\mathrm{C}_{14} \mathrm{H}_{16} \mathrm{NO}_{7} \mathrm{~S}$ : 342.06420 , found 342.06516 . EA: Anal. calcd. for $\mathrm{C}_{14} \mathrm{H}_{15} \mathrm{NO}_{7} \mathrm{~S}$ : C, $49.26 \% ; \mathrm{H}, 4.43 \%$; N, $4.10 \%$; S, $9.39 \%$; found C, $48.92 \%$; H, 4.48\%; N, 4.25\%; S, 9.41\%

\section{2-Azido-4-O-benzyl-5N,6O-(cyclic}

carbamate)-1,2dideoxynojirimycin (19) and 3-Azido-4-O-benzyl-5N,6O(cyclic carbamate)-1,3-dideoxyallonojirimycin (20)

$\mathrm{NaN}_{3}(1.06 \mathrm{~g}, 16.31 \mathrm{mmol})$ and $22(2.78 \mathrm{~g}, 8.16 \mathrm{mmol})$ were dissolved in acetone: $\mathrm{H}_{2} \mathrm{O} 2: 1(135 \mathrm{~mL})$ and heated at $50{ }^{\circ} \mathrm{C}$ for $6 \mathrm{~h}$. After removal of the acetone at low pressure, $\mathrm{Et}_{2} \mathrm{O}(80 \mathrm{~mL})$ and $20 \%$ aq $\mathrm{H}_{2} \mathrm{SO}_{4}(60 \mathrm{~mL})$ were added and the mixture was stirred at r.t. for $24 \mathrm{~h}$. The reaction was diluted with $\mathrm{H}_{2} \mathrm{O}(30$ $\mathrm{mL})$, extracted with EtOAc $(3 \times 50 \mathrm{~mL})$, washed with aqueous $\mathrm{NaHCO}_{3}(2 \times 15 \mathrm{~mL})$, dried over $\mathrm{MgSO}_{4}$, and purified by chromatography on silica gel using hexane/ethyl acetate and increasing the polarity ratio to obtain $19(979 \mathrm{mg}, 39 \%)$ and 20 $(554 \mathrm{mg}, 22 \%)$ as white solids.

19: $[\alpha]^{20} \mathrm{D}=+74.0\left(\mathrm{c}=0.37, \mathrm{CHCl}_{3}\right) . \mathrm{Mp}: 194-197{ }^{\circ} \mathrm{C} .{ }^{1} \mathrm{H}-\mathrm{NMR}$ $\left(400 \mathrm{MHz}, \mathrm{CDCl}_{3}, \delta / \mathrm{ppm}\right): 7.44-7.29(\mathrm{~m}, 5 \mathrm{H}), 4.89(\mathrm{~d}, J=$ $11.6 \mathrm{~Hz}, 1 \mathrm{H}), 4.72(\mathrm{~d}, J=11.6 \mathrm{~Hz}, 1 \mathrm{H}), 4.30(\mathrm{dd}, J=9.0,8.0$ $\mathrm{Hz}, 1 \mathrm{H}), 4.06(\mathrm{dd}, J=13.5,6.0 \mathrm{~Hz}, 1 \mathrm{H}), 3.87$ (dd, $J=9.0,4.5$ $\mathrm{Hz}, 1 \mathrm{H}), 3.59$ (dt, $J=9.5,3.5 \mathrm{~Hz}, 1 \mathrm{H}), 3.53(\mathrm{ddd}, J=9.5,8.0$, $4.5 \mathrm{~Hz}, 1 \mathrm{H}), 3.44(\mathrm{ddd}, J=11.0,9.5,6.0 \mathrm{~Hz}, 1 \mathrm{H}), 3.29(\mathrm{t}, J=$ $9.4 \mathrm{~Hz}, 1 \mathrm{H}), 2.76(\mathrm{~d}, J=3.5 \mathrm{~Hz}, 1 \mathrm{H}), 2.71(\mathrm{dd}, J=13.5,11.0$ $\mathrm{Hz}, 1 \mathrm{H}) .{ }^{13} \mathrm{C}-\mathrm{NMR}\left(100 \mathrm{MHz}, \mathrm{CDCl}_{3}, \delta / \mathrm{ppm}\right): 156.4$ (CO), $137.3(\mathrm{C}), 128.8(\mathrm{CH}), 128.6(\mathrm{CH}), 128.2(\mathrm{CH}), 80.1(\mathrm{CH})$, $77.6(\mathrm{CH}), 75.1\left(\mathrm{CH}_{2}\right), 65.6\left(\mathrm{CH}_{2}\right), 60.6(\mathrm{CH}), 56.5(\mathrm{CH}), 42.6$ $\left(\mathrm{CH}_{2}\right)$. IR (film, $v_{\max } / \mathrm{cm}^{-1}$ ): 3366, 2919, 2118, 1709, 1438, 1253, 1108, 1085. HRMS (ES): calcd. for $\mathrm{C}_{14} \mathrm{H}_{17} \mathrm{~N}_{4} \mathrm{O}_{4}$ : 305.12443, found 305.12464. EA: Anal. calcd. for $\mathrm{C}_{14} \mathrm{H}_{16} \mathrm{~N}_{4} \mathrm{O}_{4}$ : 
C, 55.26\%; H, 5.30\%; N, 18.41\%; found C, 55.35\%; H, 5.35\%; $\mathrm{N}, 18.51 \%$

20: $[\alpha]^{20} \mathrm{D}=+51.2\left(\mathrm{c}=0.43, \mathrm{CHCl}_{3}\right) . \mathrm{Mp}: 148-152{ }^{\circ} \mathrm{C} .{ }^{1} \mathrm{H}-\mathrm{NMR}$ $\left(400 \mathrm{MHz}, \mathrm{CDCl}_{3}, \delta / \mathrm{ppm}\right): 7.44-7.32(\mathrm{~m}, 5 \mathrm{H}), 4.74(\mathrm{~d}, J=$ $11.5 \mathrm{~Hz}, 1 \mathrm{H}), 4.52(\mathrm{~d}, J=11.5 \mathrm{~Hz}, 1 \mathrm{H}), 4.35(\mathrm{dd}, J=8.5,6.5$ $\mathrm{Hz}, 1 \mathrm{H}), 4.17(\mathrm{t}, J=3.0,1 \mathrm{H}), 4.03(\mathrm{~m}, 2 \mathrm{H}), 3.92(\mathrm{~m}, 2 \mathrm{H}), 3.68$ $(\mathrm{d}, J=14.5 \mathrm{~Hz}, 2 \mathrm{H}), 3.25(\mathrm{dd}, J=14.5,1.5 \mathrm{~Hz}, 1 \mathrm{H}) .{ }^{13} \mathrm{C}-\mathrm{NMR}$ (100 MHz, $\left.\mathrm{CDCl}_{3}, \delta / \mathrm{ppm}\right): 158.7(\mathrm{CO}), 136.8(\mathrm{C}), 128.7(\mathrm{CH})$, $128.4(\mathrm{CH}), 128.3(\mathrm{CH}), 74.8(\mathrm{CH}), 71.8\left(\mathrm{CH}_{2}\right), 67.5(\mathrm{CH})$, $65.9\left(\mathrm{CH}_{2}\right), 59.9(\mathrm{CH}), 53.2(\mathrm{CH}), 42.7\left(\mathrm{CH}_{2}\right)$. IR (film, $v_{\max } /$ $\mathrm{cm}^{-1}$ ): 3294, 2919, 2099, 1727, 1447, 1088, 1067. HRMS (ES): calcd. for $\mathrm{C}_{14} \mathrm{H}_{17} \mathrm{~N}_{4} \mathrm{O}_{4}$ : 305.12443 , found 305.12450 . EA: Anal. calcd. for $\mathrm{C}_{14} \mathrm{H}_{16} \mathrm{~N}_{4} \mathrm{O}_{4}$ : C, 55.26\%; $\mathrm{H}, 5.30 \% ; \mathrm{N}, 18.41 \%$; found C, $55.48 \%$; H, 5.40\%; N, $18.42 \%$.

\section{2-Azido-3,4-di-O-benzyl-5N,6O-(cyclic} dideoxynojirimycin (23)

A solution of $19(330 \mathrm{mg}, 1.08 \mathrm{mmol})$ in DMF $(8 \mathrm{~mL})$ was added via cannula to a suspension of $\mathrm{NaH}(40 \mathrm{mg}, 1.62 \mathrm{mmol})$ in DMF $(8.5 \mathrm{~mL})$ cooled at $0^{\circ} \mathrm{C}$. After $10 \mathrm{~min}$, benzyl bromide $(0.18 \mathrm{~mL}, 1.52 \mathrm{mmol})$ was added drop wise and the reaction was allowed to stir at r.t. until no starting material was observed by TLC. $\mathrm{H}_{2} \mathrm{O}(5 \mathrm{~mL})$ was then added and the reaction was extracted with $\mathrm{CH}_{2} \mathrm{Cl}_{2}$ (3x $5 \mathrm{~mL}$ ), dried over $\mathrm{MgSO}_{4}$, and purified by chromatography on silica gel using hexane/EtOAc to give $23(384 \mathrm{mg}, 90 \%)$ as a white solid. $[\alpha]^{20} \mathrm{D}=+53.4$ $\left(\mathrm{c}=0.49, \mathrm{CHCl}_{3}\right) . \mathrm{Mp}: 110-112{ }^{\circ} \mathrm{C} .{ }^{1} \mathrm{H}-\mathrm{NMR}\left(400 \mathrm{MHz}, \mathrm{CDCl}_{3}\right.$, $\delta / \mathrm{ppm}): 7.43-7.22(\mathrm{~m}, 10 \mathrm{H}), 4.91(\mathrm{dt}, J=10.5,9.5 \mathrm{~Hz}, 3 \mathrm{H})$, $4.61(\mathrm{~d}, J=11.5 \mathrm{~Hz}, 1 \mathrm{H}), 4.23(\mathrm{dd}, J=9.0,8.0 \mathrm{~Hz}, 1 \mathrm{H}), 4.04$ $(\mathrm{dd}, J=13.5,5.5 \mathrm{~Hz}, 1 \mathrm{H}), 3.70(\mathrm{dd}, J=9.0,4.5 \mathrm{~Hz}, 1 \mathrm{H}), 3.60-$ $3.40(\mathrm{~m}, 3 \mathrm{H}), 3.34(\mathrm{t}, J=9.0 \mathrm{~Hz}, 1 \mathrm{H}), 2.67(\mathrm{dd}, J=13.5,10.5$ $\mathrm{Hz}, 1 \mathrm{H}) .{ }^{13} \mathrm{C}-\mathrm{NMR}\left(100 \mathrm{MHz}, \mathrm{CDCl}_{3}, \delta / \mathrm{ppm}\right): 156.4(\mathrm{CO})$, $137.3(\mathrm{C}), 137.2(\mathrm{C}), 128.7(\mathrm{CH}), 128.5(\mathrm{CH}), 128.5(\mathrm{CH})$, $128.2(\mathrm{CH}), 128.2(\mathrm{CH}), 85.1(\mathrm{CH}), 80.0(\mathrm{CH}), 76.1\left(\mathrm{CH}_{2}\right)$, $75.1\left(\mathrm{CH}_{2}\right), 65.4\left(\mathrm{CH}_{2}\right), 60.7(\mathrm{CH}), 56.8(\mathrm{CH}), 43.0\left(\mathrm{CH}_{2}\right)$. IR (film, $v_{\max } / \mathrm{cm}^{-1}$ ): 2917, 2110, 1761, 1425, 1091. HRMS (ES): calcd. for $\mathrm{C}_{21} \mathrm{H}_{23} \mathrm{~N}_{4} \mathrm{O}_{4}$ : 395.1714, found 395.1706. EA: Anal. calcd. for $\mathrm{C}_{21} \mathrm{H}_{22} \mathrm{~N}_{4} \mathrm{O}_{4}$ : C, $63.95 \% ; \mathrm{H}, 5.62 \% ; \mathrm{N}, 14.20 \%$; found C, $63.85 \%$; H, 5.50\%; N, $14.06 \%$.

2-Acetamido-3,4-di-O-benzyl-5N,6O-(cyclic carbamate)-1,2dideoxynojirimycin (24)

$\mathrm{Pd} / \mathrm{C}(18 \mathrm{mg}, 0.02 \mathrm{mmol})$ was added to a solution of 23 (111 $\mathrm{mg}, 0.28 \mathrm{mmol})$ in EtOAc $(5 \mathrm{~mL})$ and the reaction was charged with $\mathrm{H}_{2}(5 \mathrm{barg})$ and stirred at r.t. for $20 \mathrm{~h}$. Palladium was filtered with $\mathrm{MeOH}$ over Celite and solvents were removed under low pressure. The obtained colorless oil was dissolved in pyridine $(2 \mathrm{~mL})$ and $\mathrm{Ac}_{2} \mathrm{O}(48 \mu \mathrm{L}, 0.39 \mathrm{mmol})$ was added. The reaction was stirred at r.t. for $16 \mathrm{~h} . \mathrm{H}_{2} \mathrm{O}(5 \mathrm{~mL})$ was then added and the reaction was extracted with EtOAc $(3 \mathrm{x} 5 \mathrm{~mL})$, dried over $\mathrm{MgSO}_{4}$, and purified by chromatography on silica gel using hexane/EtOAc to give $\mathbf{2 4}(110 \mathrm{mg}, 95 \%)$ as a white solid. $[\alpha]^{20} \mathrm{D}=+106.5\left(\mathrm{c}=0.31, \mathrm{CHCl}_{3}\right) . \mathrm{Mp}: 213-215{ }^{\circ} \mathrm{C} .{ }^{1} \mathrm{H}-\mathrm{NMR}$ (400 MHz, $\left.\mathrm{CDCl}_{3}, \delta / \mathrm{ppm}\right): 7.44-7.28(\mathrm{~m}, 10 \mathrm{H}), 5.33$ (d, $J=$ $5.0 \mathrm{~Hz}, 1 \mathrm{H}), 4.92(\mathrm{~d}, J=11.5 \mathrm{~Hz}, 2 \mathrm{H}), 4.66(\mathrm{dd}, J=13.0,11.5$ $\mathrm{Hz}, 2 \mathrm{H}), 4.25(\mathrm{dd}, J=9.0,8.0 \mathrm{~Hz}, 1 \mathrm{H}), 4.04(\mathrm{dd}, J=13.0,5.0$ $\mathrm{Hz}, 1 \mathrm{H}), 3.76-3.52(\mathrm{~m}, 4 \mathrm{H}), 3.39(\mathrm{~m}, 1 \mathrm{H}), 2.82(\mathrm{~m}, 1 \mathrm{H}), 1.78$ (s, 3H). ${ }^{13} \mathrm{C}-\mathrm{NMR}\left(100 \mathrm{MHz}, \mathrm{CDCl}_{3}, \delta / \mathrm{ppm}\right): 170.4(\mathrm{CO})$, $156.4(\mathrm{CO}), 137.9(\mathrm{C}), 137.4(\mathrm{C}), 128.8(\mathrm{CH}), 128.7(\mathrm{CH})$, $128.4(\mathrm{CH}), 128.4(\mathrm{CH}), 128.3(\mathrm{CH}), 128.2(\mathrm{CH}), 81.9(\mathrm{CH})$, $81.2(\mathrm{CH}), 75.0\left(\mathrm{CH}_{2}\right), 74.9\left(\mathrm{CH}_{2}\right), 65.6\left(\mathrm{CH}_{2}\right), 56.9(\mathrm{CH}), 50.5$ $(\mathrm{CH}), 42.7\left(\mathrm{CH}_{2}\right), 23.3\left(\mathrm{CH}_{3}\right)$. IR (film, $\left.v_{\max } / \mathrm{cm}^{-1}\right)$ : 3299 , 2946, 1749, 1652, 1521, 1088. HRMS (ES): calcd. for $\mathrm{C}_{23} \mathrm{H}_{27} \mathrm{~N}_{2} \mathrm{O}_{5}$ : 411.19145, found 411.19214. EA: Anal. calcd. for $\mathrm{C}_{23} \mathrm{H}_{26} \mathrm{~N}_{2} \mathrm{O}_{5}+1 / 2 \mathrm{H}_{2} \mathrm{O}: \mathrm{C}, 65.86 \% ; \mathrm{H}, 6.49 \% ; \mathrm{N}, 6.68 \%$; found $\mathrm{C}$, $65.85 \%$; H, 6.13\%; N, 6.50\%.

\section{2-Acetamido-3,4-di-O-benzyl-1,2-dideoxynojirimycin (25)}

$\mathrm{NaOH} 6 \mathrm{M}(0.35 \mathrm{~mL}, 2.11 \mathrm{mmol})$ was added to a solution of 24 (87 mg, $0.21 \mathrm{mmol})$ in $\mathrm{MeOH}: \mathrm{H}_{2} \mathrm{O}$ 9:1 (8 mL) and the reaction was stirred at reflux for $4 \mathrm{~h} . \mathrm{H}_{2} \mathrm{O}(5 \mathrm{~mL})$ was then added and the reaction was extracted with EtOAc $(3 \times 5 \mathrm{~mL})$, dried over $\mathrm{MgSO}_{4}$, and purified by chromatography on silica gel using $\mathrm{CH}_{2} \mathrm{Cl}_{2} / \mathrm{MeOH}$ to give $25(75 \mathrm{mg}, 92 \%)$ as a white solid. $[\alpha]^{20}{ }_{\mathrm{D}}=-19.7\left(\mathrm{c}=0.08, \mathrm{CH}_{3} \mathrm{OH}\right) . \mathrm{Mp}: 210-212{ }^{\circ} \mathrm{C} .{ }^{1} \mathrm{H}-$ NMR (400 MHz, CD $3 \mathrm{OD}, \delta / \mathrm{ppm}): 7.34-7.24(\mathrm{~m}, 10 \mathrm{H}), 4.81$ $(\mathrm{dd}, J=11.0,1.5 \mathrm{~Hz}, 2 \mathrm{H}), 4.73(\mathrm{~d}, J=18.0 \mathrm{~Hz}, 1 \mathrm{H}), 4.67(\mathrm{~d}, J$ $=18.0 \mathrm{~Hz}, 1 \mathrm{H}), 3.97(\mathrm{~m}, 1 \mathrm{H}), 3.79(\mathrm{dd}, J=11.0,2.5 \mathrm{~Hz}, 1 \mathrm{H})$, $3.68(\mathrm{dd}, J=11.0,5.0 \mathrm{~Hz}, 1 \mathrm{H}), 3.44(\mathrm{~m}, 2 \mathrm{H}), 3.04(\mathrm{dd}, J=$ 12.0, $5.0 \mathrm{~Hz}, 1 \mathrm{H}), 2.55(\mathrm{~m}, 1 \mathrm{H}), 2.44(\mathrm{t}, J=12.0 \mathrm{~Hz}, 1 \mathrm{H}), 1.88$ (s, 3H). ${ }^{13} \mathrm{C}-\mathrm{NMR}\left(100 \mathrm{MHz}, \mathrm{CD}_{3} \mathrm{OD}, \delta / \mathrm{ppm}\right): 173.1$ (CO), $140.2(\mathrm{C}), 139.8(\mathrm{C}), 129.4(\mathrm{CH}), 129.3(\mathrm{CH}), 128.9(\mathrm{CH})$, $128.7(\mathrm{CH}), 128.7(\mathrm{CH}), 128.6(\mathrm{CH}), 86.4(\mathrm{CH}), 81.5(\mathrm{CH})$, $76.0\left(\mathrm{CH}_{2}\right), 62.6(\mathrm{CH}), 62.2\left(\mathrm{CH}_{2}\right), 53.3(\mathrm{CH}), 49.3\left(\mathrm{CH}_{2}\right), 22.9$ $\left(\mathrm{CH}_{3}\right)$. IR (film, $\left.v_{\max } / \mathrm{cm}^{-1}\right): 3275,2933,1650,1554,1072$, 1027. HRMS (ES): calcd. for $\mathrm{C}_{22} \mathrm{H}_{29} \mathrm{~N}_{2} \mathrm{O}_{4}: 385.21218$, found 385.21223. EA: Anal. calcd. for $\mathrm{C}_{22} \mathrm{H}_{28} \mathrm{~N}_{2} \mathrm{O}_{4}+3 / 2 \mathrm{H}_{2} \mathrm{O}$ : C, $64.21 \%$; H, 7.59\%; N, 6.81\%; found C, $64.52 \%$; H, 7.08\%; N, $6.42 \%$.

\section{2-Acetamido-1,2-dideoxynojirimycin (DNJNAc, 4)}

To a solution of $25(20 \mathrm{mg}, 0.05 \mathrm{mmol})$ in $\mathrm{MeOH}(4 \mathrm{~mL})$ was added $\mathrm{Pd} / \mathrm{C}(9 \mathrm{mg}, 0.008 \mathrm{mmol})$ and the reaction was charged with $\mathrm{H}_{2}$ (55 barg) and stirred at $60{ }^{\circ} \mathrm{C}$ for $20 \mathrm{~h}$. Palladium was then filtrated over Celite and the crude was purified by chromatography on silica gel using $\mathrm{CH}_{2} \mathrm{Cl}_{2} / \mathrm{MeOH} / \mathrm{NH}_{3}$ 72.5:25:2.5 to give $4(12 \mathrm{mg}, 96 \%)$ as a white solid. $[\alpha]^{20}{ }_{\mathrm{D}}=$ $+7.9\left(\mathrm{c}=0.15, \mathrm{H}_{2} \mathrm{O}\right) . \mathrm{Mp}: 210-212{ }^{\circ} \mathrm{C} .{ }^{1} \mathrm{H}-\mathrm{NMR}(400 \mathrm{MHz}$, $\left.\mathrm{CD}_{3} \mathrm{OD}, \delta / \mathrm{ppm}\right): 3.81(\mathrm{dd}, J=11.0,3.0 \mathrm{~Hz}, 1 \mathrm{H}), 3.73(\mathrm{~m}, 1 \mathrm{H})$, $3.63(\mathrm{dd}, J=11.0,6.0 \mathrm{~Hz}, 1 \mathrm{H}), 3.24(\mathrm{~m}, 2 \mathrm{H}), 3.11(\mathrm{dd}, J=$ $12.5,5.0 \mathrm{~Hz}, 1 \mathrm{H}), 2.46(\mathrm{ddd}, J=9.5,6.0,3.0 \mathrm{~Hz}, 1 \mathrm{H}), 2.38(\mathrm{dd}$, $J=12.5,11.0 \mathrm{~Hz}, 1 \mathrm{H}), 1.96(\mathrm{~s}, 3 \mathrm{H}) .{ }^{13} \mathrm{C}-\mathrm{NMR}(100 \mathrm{MHz}$, $\left.\mathrm{CD}_{3} \mathrm{OD}, \delta / \mathrm{ppm}\right): \quad 173.6(\mathrm{CO}), 77.7(\mathrm{CH}), 73.9(\mathrm{CH}), 62.8$ $\left(\mathrm{CH}_{2}\right), 62.7(\mathrm{CH}), 53.9(\mathrm{CH}), 49.1\left(\mathrm{CH}_{2}\right), 22.7\left(\mathrm{CH}_{3}\right)$. IR (film, $\left.v_{\max } / \mathrm{cm}^{-1}\right): 3287,2917,1638,1559,1437,1373,1096,1040$. HRMS (ES): calcd. for $\mathrm{C}_{8} \mathrm{H}_{17} \mathrm{~N}_{2} \mathrm{O}_{4}:$ 205.11828, found 205.11784.

\section{2-Azido-4- $O$-benzyl-5- $N$-benzyloxycarbonyl-1,2-} dideoxynojirimycin (30)

$\mathrm{NaOH} 6 \mathrm{M}(2 \mathrm{~mL}, 11.89 \mathrm{mmol})$ was added to a solution of compound 19 (301 mg, $0.99 \mathrm{mmol})$ in $\mathrm{MeOH}: \mathrm{H}_{2} \mathrm{O}$ 9:1 $(20 \mathrm{~mL})$ and the reaction was heated at reflux for $15 \mathrm{~h}$. Solvent was then removed under low pressure and the crude was redissolved in EtOAc: $\mathrm{NaHCO}_{3}$ saturated aqueous 1:1 $(14 \mathrm{~mL})$. After $30 \mathrm{~min}$ of stirring, $\mathrm{Boc}_{2} \mathrm{O}$ (436 mg, $1.91 \mathrm{mmol}$ ) was added and the crude was allowed to stir for $24 \mathrm{~h}$. The crude was treated with water $(6 \mathrm{~mL})$, extracted with EtOAc $(3 \times 5 \mathrm{~mL})$, dried with $\mathrm{MgSO}_{4}$, and purified by chromatography on silica gel using hexane/ethyl acetate to give $30(334 \mathrm{mg}, 90 \%)$ as a colorless oil. $[\alpha]^{20} \mathrm{D}=-36.1\left(\mathrm{c}=0.67, \mathrm{CHCl}_{3}\right) .{ }^{1} \mathrm{H}-\mathrm{NMR}(400 \mathrm{MHz}$, $\left.\mathrm{CDCl}_{3}, \delta / \mathrm{ppm}\right): 7.38-7.28(\mathrm{~m}, 5 \mathrm{H}), 4.83(\mathrm{~d}, J=11.5 \mathrm{~Hz}, 1 \mathrm{H})$, $4.72(\mathrm{~d}, J=11.5 \mathrm{~Hz}, 1 \mathrm{H}), 4.00(\mathrm{~d}, J=11.0 \mathrm{~Hz}, 1 \mathrm{H}), 3.97-3.87$ (br, 2H), $3.84(\mathrm{dd}, J=14.0,4.5 \mathrm{~Hz}, 1 \mathrm{H}), 3.68(\mathrm{t}, J=7.0 \mathrm{~Hz}$, $1 \mathrm{H}), 3.57$ (t, $J=7.0 \mathrm{~Hz}, 1 \mathrm{H}), 3.53(\mathrm{br}, 1 \mathrm{H}), 3.39(\mathrm{td}, J=7.5$, $4.5 \mathrm{~Hz}, 1 \mathrm{H}), 3.29(\mathrm{~s}, 1 \mathrm{H}), 3.18(\mathrm{dd}, J=14.0,7.5 \mathrm{~Hz}, 1 \mathrm{H}), 1.47$ (s, 9H). ${ }^{13} \mathrm{C}-\mathrm{NMR}\left(100 \mathrm{MHz}, \mathrm{CDCl}_{3}, \delta / \mathrm{ppm}\right): 154.9$ (CO), $138.0(\mathrm{C}), 128.6(\mathrm{CH}), 128.0(\mathrm{CH}), 128.0(\mathrm{CH}), 81.5(\mathrm{~s}), 77.7$ (C), $75.4(\mathrm{CH}), 74.1\left(\mathrm{CH}_{2}\right), 60.8(\mathrm{CH}), 60.7\left(\mathrm{CH}_{2}\right), 60.6(\mathrm{CH})$, $45.7\left(\mathrm{CH}_{2}\right), 28.3\left(\mathrm{CH}_{3}\right)$. IR (film, $\left.v_{\max } / \mathrm{cm}^{-1}\right)$ : 3404, 2968, 2107, 1668, 1422, 1367, 1250, 1162. HRMS (ES): calcd. for $\mathrm{C}_{18} \mathrm{H}_{27} \mathrm{~N}_{4} \mathrm{O}_{5}: 379.19760$, found 379.19777 . 


\section{2-Acetamido-3,4-6-tri- $O$-acetyl-5- $N$-benzyloxycarbonyl-1,2-} dideoxynojirimycin (31)

$\mathrm{Pd} / \mathrm{C}(160 \mathrm{mg}, 0.15 \mathrm{mmol})$ and acetic acid $(0.43 \mathrm{~mL}, 7.55$ mmol) were added to a solution of $\mathbf{3 0}(571 \mathrm{mg}, 1.51 \mathrm{mmol})$ in degassed $\mathrm{MeOH}(15 \mathrm{~mL})$ and the reaction was charged with $\mathrm{H}_{2}$ (15 barg) and stirred at $60^{\circ} \mathrm{C}$ for $16 \mathrm{~h}$. Palladium was filtered over Celite and solvents were removed under low pressure. The colorless obtained oil was redissolved in pyridine $(10 \mathrm{~mL})$ and $\mathrm{Ac}_{2} \mathrm{O}(1.58 \mathrm{~mL}, 15.02 \mathrm{mmol})$ was added. The reaction was stirred at r.t. for $16 \mathrm{~h} . \mathrm{H}_{2} \mathrm{O}(5 \mathrm{~mL})$ was then added and the reaction was extracted with $\mathrm{CH}_{2} \mathrm{Cl}_{2}(3 \mathrm{x} 5 \mathrm{~mL})$, dried over $\mathrm{MgSO}_{4}$ and purified by chromatography on silica gel using hexane/EtOAc to give $31(538 \mathrm{mg}, 83 \%)$ as a colorless oil. $[\alpha]^{20} \mathrm{D}=-7.2\left(\mathrm{c}=2.3, \mathrm{CHCl}_{3}\right) .{ }^{1} \mathrm{H}-\mathrm{NMR}\left(400 \mathrm{MHz}, \mathrm{CD}_{3} \mathrm{OD}\right.$, $\delta / \mathrm{ppm}): 6.12(\mathrm{~d}, J=8.5 \mathrm{~Hz}, 1 \mathrm{H}), 4.94(\mathrm{~m}, 1 \mathrm{H}), 4.92(\mathrm{~m}, 1 \mathrm{H})$, $4.61(\mathrm{t}, J=7.5 \mathrm{~Hz}, 1 \mathrm{H}), 4.38(\mathrm{dd}, J=11.5,8.5 \mathrm{~Hz}, 1 \mathrm{H}), 4.23$ (dd, $J=11.5,6.5 \mathrm{~Hz}, 1 \mathrm{H}), 4.14-4.05(\mathrm{~m}, 2 \mathrm{H}), 3.32(\mathrm{dd}, J=$ 15.0, 3.0 Hz, 1H), $2.11(\mathrm{~s}, 6 \mathrm{H}), 2.06(\mathrm{~s}, 3 \mathrm{H}), 1.99(\mathrm{~s}, 3 \mathrm{H}), 1.47$ (s, 9H). ${ }^{13} \mathrm{C}-\mathrm{NMR}\left(100 \mathrm{MHz}, \mathrm{CD}_{3} \mathrm{OD}, \delta / \mathrm{ppm}\right): 170.4(\mathrm{CO})$, $168.9(\mathrm{CO}), 168.6(\mathrm{CO}), 168.2(\mathrm{CO}), 155.5(\mathrm{CO}), 80.8(\mathrm{C})$, $67.8(\mathrm{CH}), 67.0(\mathrm{CH}), 59.9\left(\mathrm{CH}_{2}\right), 52.9(\mathrm{CH}), 46.1(\mathrm{CH}), 39.3$ $\left(\mathrm{CH}_{2}\right), 28.2\left(\mathrm{CH}_{3}\right), 23.3\left(\mathrm{CH}_{3}\right), 20.8\left(\mathrm{CH}_{3}\right), 20.8\left(\mathrm{CH}_{3}\right), 20.7$ $\left(\mathrm{CH}_{3}\right)$. IR (film, $\left.v_{\max } / \mathrm{cm}^{-1}\right): 3333,2975,1745,1687,1369$, 1223, 1046. HRMS (ES): calcd. for $\mathrm{C}_{19} \mathrm{H}_{31} \mathrm{~N}_{2} \mathrm{O}: 431.20241$, found 431.20239 .

\section{2-Acetamido-3,4-6-tri-O-acetyl-5- $N$ - $\left(N^{\prime}\right.$ -}

\section{butylaminocarbonyl)-1,2-dideoxynojirimycin (32a)}

TFA $(0.48 \mathrm{~mL}, 6.31 \mathrm{mmol})$ was added to a solution of $\mathbf{3 1}$ (90 $\mathrm{mg}, 0.21 \mathrm{mmol})$ in $\mathrm{CH}_{2} \mathrm{Cl}_{2}(8 \mathrm{~mL})$ and the reaction was stirred at r.t. until no starting material was observed by TLC. Solvent was removed under reduced pressure and the resulting oil was dissolved in $\mathrm{CH}_{2} \mathrm{Cl}_{2}(8 \mathrm{~mL})$. TEA $(0.23 \mathrm{~mL}, 1.64 \mathrm{mmol})$ and butyl isocyanate $(71 \mu 1,0.63 \mathrm{mmol})$ were added and the reaction was heated at reflux for $4 \mathrm{~h} . \mathrm{H}_{2} \mathrm{O}(5 \mathrm{~mL})$ was then added and the reaction was extracted with $\mathrm{CH}_{2} \mathrm{Cl}_{2}(3 \times 5 \mathrm{~mL})$, dried over $\mathrm{MgSO}_{4}$, and purified by chromatography on silica gel using $\mathrm{CH}_{2} \mathrm{Cl}_{2} / \mathrm{MeOH}$ to give 32a (73 $\mathrm{mg}, 81 \%$ ) as a colorless oil. $[\alpha]^{20} \mathrm{D}=-63.5\left(\mathrm{c}=2.31, \mathrm{CHCl}_{3}\right) .{ }^{1} \mathrm{H}-\mathrm{NMR}\left(400 \mathrm{MHz}, \mathrm{CDCl}_{3}\right.$, $\delta / \mathrm{ppm}): 6.52(\mathrm{~d}, J=8.0 \mathrm{~Hz} 1 \mathrm{H}), 5.04(\mathrm{t}, J=5.5 \mathrm{~Hz} 1 \mathrm{H}), 4.99(\mathrm{t}$ $J=3.0 \mathrm{~Hz} 1 \mathrm{H}), 4.88(\mathrm{~m}, 1 \mathrm{H}), 4.43(\mathrm{dd}, J=11.0,7.5 \mathrm{~Hz}, 1 \mathrm{H})$, $4.24(\mathrm{t}, J=6.5 \mathrm{~Hz}, 1 \mathrm{H}), 4.12(\mathrm{dd}, J=11.0,7.5 \mathrm{~Hz}, 1 \mathrm{H}) 4.03(\mathrm{q}$ $J=3.5 \mathrm{~Hz}, 1 \mathrm{H}), 3.95(\mathrm{~d}, J=5.0 \mathrm{~Hz}, 1 \mathrm{H}), 3.26(\mathrm{dd}, J=15.0,3.0$ $\mathrm{Hz}, 1 \mathrm{H}), 3.20(\mathrm{~m}, 2 \mathrm{H}), 2.09$ (s, 3H), 2.07 (s, 3H), 2.04 (s, 3H), 1.95 (s, 3H), 1.47 (p, $J=7.0 \mathrm{~Hz}, 2 \mathrm{H}),(\mathrm{h}, J=7.0 \mathrm{~Hz}, 2 \mathrm{H}), 0.90$ $(\mathrm{t}, J=7.5 \mathrm{~Hz}, 3 \mathrm{H}) .{ }^{13} \mathrm{C}-\mathrm{NMR}\left(100 \mathrm{MHz}, \mathrm{CDCl}_{3}, \delta / \mathrm{ppm}\right): 171.0$ (CO), $169.6(\mathrm{CO}), 168.8(\mathrm{CO}), 168.7(\mathrm{CO}), 159.0(\mathrm{CO}), 68.0$ $(\mathrm{CH}), 67.0(\mathrm{CH}), 61.0\left(\mathrm{CH}_{2}\right), 54.0(\mathrm{CH}), 47.0(\mathrm{CH}), 40.8$ $\left(\mathrm{CH}_{2}\right), 39.1\left(\mathrm{CH}_{2}\right), 32.1\left(\mathrm{CH}_{2}\right), 23.2\left(\mathrm{CH}_{3}\right), 20.8\left(\mathrm{CH}_{3}\right), 20.8$ $\left(\mathrm{CH}_{3}\right), 20.7\left(\mathrm{CH}_{3}\right), 20.0\left(\mathrm{CH}_{2}\right), 13.7\left(\mathrm{CH}_{3}\right)$. IR (film, $v_{\max } / \mathrm{cm}^{-}$ $\left.{ }^{1}\right): 3364,2958,2932,1749,1652,1539,1370,1225,1043$. HRMS (ES): calcd. for $\mathrm{C}_{19} \mathrm{H}_{32} \mathrm{~N}_{3} \mathrm{O}_{8}: 430.21819$, found 430.21839

\section{2-Acetamido-5- $N$-( $N$ '-butylaminocarbonyl)-1,2-} dideoxynojirimycin (10a)

Compound 32a (73 mg, $0.17 \mathrm{mmol})$ was dissolved in a $\mathrm{NH}_{3}$ saturated $\mathrm{MeOH}$ solution $(4 \mathrm{~mL})$ and the reaction was stirred at r.t. for $18 \mathrm{~h}$. Solvent was removed under low pressure, and the crude was purified by chromatography on silica gel using $\mathrm{CH}_{2} \mathrm{Cl}_{2} / \mathrm{MeOH}$ to give 10a (32 $\left.\mathrm{mg}, 61 \%\right)$ as a slightly yellow solid. $[\alpha]^{20} \mathrm{D}=+25.0\left(\mathrm{c}=1.63, \mathrm{CH}_{3} \mathrm{OH}\right) . \mathrm{Mp}: 70-72{ }^{\circ} \mathrm{C} .{ }^{1} \mathrm{H}-\mathrm{NMR}$ $\left(400 \mathrm{MHz}, \mathrm{CD}_{3} \mathrm{OD}, \delta / \mathrm{ppm}\right): 3.94(\mathrm{~m}, 1 \mathrm{H}), 3.91-3.81(\mathrm{~m}$, $3 \mathrm{H}), 3.76(\mathrm{dd}, J=11.0,4.5 \mathrm{~Hz}, 1 \mathrm{H}), 3.72(\mathrm{t}, J=4.5 \mathrm{~Hz}, 1 \mathrm{H})$, $3.60(\mathrm{t}, J=4.5 \mathrm{~Hz}, 1 \mathrm{H}), 3.35(\mathrm{dd}, J=13.5,3.0 \mathrm{~Hz}, 1 \mathrm{H}), 3.24-$ $3.07(\mathrm{~m}, 2 \mathrm{H}), 1.95(\mathrm{~s}, 3 \mathrm{H}), 1.48(\mathrm{~m}, 2 \mathrm{H}), 1.37(\mathrm{~m}, 2 \mathrm{H}), 0.93(\mathrm{t}$
$J=7.5 \mathrm{~Hz}, 3 \mathrm{H}) .{ }^{13} \mathrm{C}-\mathrm{NMR}\left(100 \mathrm{MHz}, \mathrm{CD}_{3} \mathrm{OD}, \delta / \mathrm{ppm}\right): 172.7$ (CO), $161.8(\mathrm{CO}), 71.7(\mathrm{CH}), 70.3(\mathrm{CH}), 61.9(\mathrm{CH}), 61.8$ $\left(\mathrm{CH}_{2}\right), 51.6(\mathrm{CH}), 41.6\left(\mathrm{CH}_{2}\right), 41.0\left(\mathrm{CH}_{2}\right), 33.3\left(\mathrm{CH}_{2}\right), 22.9$ $\left(\mathrm{CH}_{3}\right), 21.1\left(\mathrm{CH}_{2}\right), 14.2\left(\mathrm{CH}_{3}\right) . \mathrm{IR}\left(\mathrm{film}, v_{\max } / \mathrm{cm}^{-1}\right): 3353$, 2923, 1623, 1540, 1469, 1418, 1021. HRMS (ES): calcd. for $\mathrm{C}_{13} \mathrm{H}_{26} \mathrm{~N}_{3} \mathrm{O}_{5}$ : 304.18670 , found 304.18727.

\section{General Procedures for Inhibition Assay}

The glycosidases $\alpha$-glucosidase (from yeast), amyloglucosidase (from Aspergillus niger), isomaltase (from yeast), $\beta$ glucosidases (from almond and bovine liver), naringinase (Penicillium decumbes), $\alpha$-galactosidase (from green coffee beans), $\beta$-galactosidase (from Escherichia coli), $\alpha$-mannosidase (from jack bean), $\beta$-mannosidase (from Helix pomatia), $\beta-N$ acetylglucosaminidases (from human placenta, bovine kidney and jack bean) used in the inhibition studies, as well as the corresponding $o$ - or $p$-nitrophenyl glycoside substrates, were purchased from Sigma Chemical Co. Inhibitory potencies were determined by spectrophotometrically measuring the residual hydrolytic activities of the glycosidases against the respective $o$ - (for $\beta$-galactosidases) or $p$-nitrophenyl $\alpha$ - or $\beta$-Dglycopyranoside (for $\alpha$-glucosidases, $\beta$-glucosidases, $\alpha$ galactosidases, $\alpha$-mannosidases and $\beta$-mannosidases) or $p$ nitrophenyl- $N$-acetyl- $\beta$-D-glucosaminide/galactosaminide (for hexosaminidases), in the presence of corresponding iminosugars. Each assay was performed in phosphate-citrate (for $\alpha$ - or $\beta$-mannosidase, amyloglucosidase or $\beta-N$ acetylglucosaminidase at $\mathrm{pH} 5.5$ or 3.5) or in phosphate buffer (at $\mathrm{pH} 7.3$ or 6.8 for the other glycosidases) at the optimal $\mathrm{pH}$ for each enzyme. The $K_{\mathrm{m}}$ values for the different glycosidases used in the tests and the corresponding working $\mathrm{pHs}$ are listed herein: $\alpha$-glucosidase (yeast), $K_{\mathrm{m}}=0.35 \mathrm{mM}(\mathrm{pH}$ 6.8); amyloglucosidase (Aspergillus niger), $K_{\mathrm{m}}=3.0 \mathrm{mM}(\mathrm{pH} 5.5)$; isomaltase (from yeast), $K_{\mathrm{m}}=1.0 \mathrm{mM}$ (pH 6.8); $\beta$-glucosidase (almond), $K \mathrm{~m}=3.5 \mathrm{mM}$ (pH 7.3); $\beta$-glucosidase (bovine liver), $K_{\mathrm{m}}=1.0 \mathrm{mM}(\mathrm{pH} 7.3)$; naringinase (Penicillium decumbes), $K_{\mathrm{m}}$ $=2.7 \mathrm{mM}$ (pH 6.8); $\alpha$-galactosidase (coffee beans), $K_{\mathrm{m}}=2.0$ $\mathrm{mM}$ ( $\mathrm{pH}$ 6.8); $\beta$-galactosidase (from Escherichia coli), $\mathrm{Km}=$ $0.12 \mathrm{mM}$ (pH 7.3); $\alpha$-mannosidase (jack bean), $K_{\mathrm{m}}=2.0 \mathrm{mM}$ $(\mathrm{pH} 5.5) ; \beta$-mannosidase (Helix pomatia), $K_{\mathrm{m}}=0.6 \mathrm{mM}(\mathrm{pH}$ 5.5); $\beta$ - $N$-acetylglucosaminidase (from human placenta), $K_{\mathrm{m}}=$ $0.34 \mathrm{mM}(\mathrm{pH} 5.5) ; \beta-N$-acetylglucosaminidase (from bovine kidney), $K_{\mathrm{m}}=0.48 \mathrm{mM}(\mathrm{pH} 5.5) ; \beta-N$-acetylglucosaminidase (from jack bean), $K_{\mathrm{m}}=0.49 \mathrm{mM}$ ( $\mathrm{pH} 5.5$ ). The reactions were initiated by addition of enzyme to a solution of the substrate in the absence or presence of various concentrations of inhibitor. After the mixture was incubated for $10-30 \mathrm{~min}$ at $37^{\circ} \mathrm{C}$ (or 55 ${ }^{\circ} \mathrm{C}$ for amyloglucosidase), the reaction was quenched by addition of $1 \mathrm{M} \mathrm{Na} \mathrm{NO}_{3}$. The absorbance of the resulting mixture was determined at $405 \mathrm{~nm}$. The $K_{\mathrm{i}}$ value and enzyme inhibition mode were determined from the slope of Lineweaver-Burk plots and double reciprocal analysis using Microsoft Office Excel 2007 program. Inhibition mode was competitive in all cases.

\section{Acknowledgements}

We thank the Spanish Ministerio de Economia $y$ Competitividad (CTQ2011-23620, SAF2013-44021R and CTQ2010-15848), the Junta de Andalucia (Project FQM-1467), and IRB Barcelona for financial support. Co-finacing by the European Union (FEDER and FSE) is also acknowledged. A.F. and T. M.-B. thank the Ministerio de Ciencia e Innovación and the Junta de Andalucia for doctoral and post-doctoral fellowships, respectively. Technical assistance from the CITIUS (Universidad de Sevilla) is recognized. 


\section{Notes and references}

${ }^{a}$ Institute for Research in Biomedicine (IRB Barcelona), Baldiri Reixac 10, E-08028 Barcelona, Spain.

${ }^{b}$ Departamento de Química Orgánica, Facultad de Química, Universidad de Sevilla, Apartado 1203, E-41071 Sevilla, Spain.

${ }^{c}$ Departament de Química Orgànica, Universitat de Barcelona, Martí i Franquès, 1. E-08028, Barcelona, Spain

${ }^{d}$ Instituto de Investigaciones Químicas (IIQ), CSIC - Universidad de Sevilla, Américo Vespucio 49, Isla de la Cartuja, E-41092 Sevilla, Spain.

$\dagger$ Cambridge Crystallographic Data Centre. The data have been assigned to the following deposition numbers: CCDC 1053544 and 1053545 .

Electronic Supplementary Information (ESI) available: Experimental procedures for the synthesis of 3-acetamido-1,3-dideoxyaltronojirimycin (29), and derivatives 32b-d and 10b-d. ${ }^{1} \mathrm{H}$ and ${ }^{13} \mathrm{C}$ spectra of all new compounds and selected Lineweaver-Burk plots of ureido-DNJNAc derivative 10c. See DOI: 10.1039/b000000x/

P. Compain and O. R. Martin, Eds., Iminosugars: from synthesis to therapeutic applications, John Wiley \& Sons, Ltd, Chichester, England, 1st edn., 2007.

2. E. Borges de Melo, A. da Silveira Gomes, and I. Carvalho, Tetrahedron, 2006, 62, 10277-10302.

3. N. Asano, Glycobiology, 2003, 13, 93R-104R.

4. B. G. Winchester, Tetrahedron: Asymmetry, 2009, 20, 645-651.

5. R. J. Nash, A. Kato, C.-Y. Yu, and G. W. Fleet, Future Med. Chem., 2011, 3, 1513-1521.

6. G. Horne, F. X. Wilson, J. Tinsley, D. H. Williams, and R. Storer, Drug Discov. Today, 2011, 16, 107-118.

7. J.-S. Zhu, S. Nakagawa, W. Chen, I. Adachi, Y.-M. Jia, X.-G. Hu, G. W. J. Fleet, F. X. Wilson, T. Nitoda, G. Horne, R. van Well, A. Kato, and C.-Y. Yu, J. Org. Chem., 2013, 78, 10298-10309.

8. Y. Nishimura, T. Satoh, T. Kudo, S. Kondo, and T. Takeuchi, Bioorg. Med. Chem., 1996, 4, 91-96

9. B. Shanmugasundaram, A. W. Debowski, R. J. Dennis, G. J. Davies, D. J. Vocadlo, and A. Vasella, Chem. Commun., 2006, 10, 4372-4374.

10. M. Terinek and A. Vasella, Helv. Chim. Acta, 2005, 88, 10-22.

11. Y. Blériot, N. Auberger, Y. Jagadeesh, C. Gauthier, G. Prencipe, A. Yamamoto, A. Kato, and M. Sollogoub, Org. Lett., 2014, 16, 5512-5515.

12. Y. Blériot, A. T. Tran, G. Prencipe, Y. Jagadeesh, N. Auberger, S. Zhu, C. Gauthier, Y. Zhang, J. Desiré, I. Adachi, A. Kato, and M. Sollogoub, Org. Lett., 2014, 16, 5516-5519.

13. G. W. J. Fleet, P. W. Smith, R. J. Nash, L. E. Fellows, R. B. Parekh, and T. W. Rademacher, Chem. Lett., 1986, 7, 1051-1054.

14. G. W. J. Fleet, L. E. Fellows, and P. W. Smith, Tetrahedron, 1987, 43, 979-990.

15. T. Kajimoto, K. K. C. Liu, R. L. Pederson, Z. Zhong, Y. Ichikawa, J. A. Porco Jr., and C. H. Wong, J. Am. Chem. Soc., 1991, 113, $6187-6196$
T. Yamaguchi, B. Blázquez, D. Hesek, M. Lee, L. I. Llarrull, B. Boggess, A. G. Oliver, J. F. Fisher, and S. Mobashery, ACS Med. Chem. Lett., 2012, 3, 238-242.
17.

18.

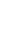

19.

20.

21.

23. S. Al-Rawi, S. Hinderlich, W. Reutter, and A. Giannis, Angew. Chemie, Int. Ed., 2004, 43, 4366-4370.

A. F. G. Glawar, D. Best, B. J. Ayers, S. Miyauchi, S. Nakagawa, M. Aguilar-Moncayo, J. M. Garcia-Fernandez, C. Ortiz Mellet, E. V Crabtree, T. D. Butters, F. X. Wilson, A. Kato, and G. W. J. Fleet, Chem. Eur. J., 2012, 18, 9341-9359.

D. Best, P. Chairatana, A. F. G. Glawar, E. Crabtree, T. D. Butters, F. X. Wilson, C.-Y. Yu, W.-B. Wang, Y.-M. Jia, I. Adachi, A. Kato, and G. W. J. Fleet, Tetrahedron Lett., 2010, 51, 2222-2224.

J. S. S. Rountree, T. D. Butters, M. R. Wormald, S. D. Boomkamp, R. A. Dwek, N. Asano, K. Ikeda, E. L. Evinson, R. J. Nash, and G. W. J. Fleet, ChemMedChem, 2009, 4, 378-392.

E. V Crabtree, R. F. Martínez, S. Nakagawa, I. Adachi, T. D. Butters, A. Kato, G. W. J. Fleet, and A. F. G. Glawar, Org. Biomol. Chem., 2014, 12, 3932-3943.

H. Li, F. Marcelo, C. Bello, P. Vogel, T. D. Butters, A. P. Rauter, Y. Zhang, M. Sollogoub, and Y. Blériot, Bioorg. Med. Chem., 2009, 17, 5598-5604.

F. Liu, K. Iqbal, I. Grundke-Iqbal, G. W. Hart, and C.-X. Gong, Proc. Natl. Acad. Sci. U. S. A., 2004, 101, 10804-10809.

S. Cecioni and D. J. Vocadlo, Curr. Opin. Chem. Biol., 2013, 17, 719-728.

M. S. Macauley, Y. He, T. M. Gloster, K. A. Stubbs, G. J. Davies, and D. J. Vocadlo, Chem. Biol., 2010, 17, 937-948.

T. M. Wrodnigg, A. J. Steiner, and B. J. Ueberbacher, Anticancer. Agents Med. Chem., 2008, 8, 77-85.

J. Liu, A. R. Shikhman, M. K. Lotz, and C. H. Wong, Chem. Biol., 2001, 8, 701-711.

R. E. Boyd, G. Lee, P. Rybczynski, E. R. Benjamin, R. Khanna, B. A. Wustman, and K. J. Valenzano, J. Med. Chem., 2013, 56, 2705 2725.

M. B. Tropak, S. P. Reid, M. Guiral, S. G. Withers, and D. Mahuran, J. Biol. Chem., 2004, 279, 13478-13487.

N. E. Clark, M. C. Metcalf, D. Best, G. W. J. Fleet, and S. C. Garman, Proc. Natl. Acad. Sci. U. S. A., 2012, 109, 17400-17405.

R. Giugliani, A. Federhen, A. A. Silva, C. Matzenbacher, C. F. Moura, C. Brinckmann, O. Netto, F. Quos Mayer, G. Baldo, and U. Matte, Res. Reports Endocr. Disord., 2012, 2, 53-64.

S. Knapp, D. Vocadlo, Z. Gao, B. Kirk, J. Lou, and S. G. Withers, J. Am. Chem. Soc., 1996, 118, 6804-6805.

T. Sumida, K. a Stubbs, M. Ito, and S. Yokoyama, Org. Biomol. Chem., 2012, 10, 2607-2612.

B. Pluvinage, K. A. Stubbs, M. Hattie, D. J. Vocadlo, and A. B. Boraston, Org. Biomol. Chem., 2013, 11, 7907-7915.

K. Afarinkia and A. Bahar, Tetrahedron: Asymmetry, 2005, 16, 1239-1287.

M. S. M. Pearson, M. Mathe-Allainmat, V. Fargeas, and J. Lebreton, Eur. J. Org. Chem., 2005, 2159-2191.

I. Dragutan, V. Dragutan, and A. Demonceau, $R S C A d v$., 2012, 2, 719-736.

V. M. Kasture, N. B. Kalamkar, R. J. Nair, R. S. Joshi, S. G. Sabharwal, and D. D. Dhavale, Carbohydr. Res., 2015, 408, 25-32. 
39. A. Siriwardena, D. P. Sonawane, O. P. Bande, P. R. Markad, S. Yonekawa, M. B. Tropak, S. Ghosh, B. A. Chopade, D. J. Mahuran, and D. D. Dhavale, J. Org. Chem., 2014, 79, 4398-4404.

40. G. Gradnig, G. Legler, and A. E. Stuetz, Carbohydr. Res., 1996, 287, 49-57.

41. M. Kiso, M. Kitagawa, H. Ishida, and A. Hasegawa, J. Carbohydr. Chem., 1991, 10, 25-45.

42. A. de la Fuente, R. Martin, T. Mena-Barragán, X. Verdaguer, J. M. García Fernández, C. Ortiz Mellet, and A. Riera, Org. Lett., 2013, 15, 3638-3641.

43. J. L. Jiménez Blanco, V. M. Diaz Pérez, C. Ortiz Mellet, J. Fuentes, J. M. Garcia Fernandez, J. C. Diaz Arribas, and F. J. Cañada, Chem. Commun., 1997, 45, 1969-1970.

44. M. I. García-Moreno, D. Rodríguez-Lucena, C. Ortiz Mellet, and J. M. García Fernández, J. Org. Chem., 2004, 69, 3578-3581.

45. E. M. Sánchez-Fernández, E. Álvarez, C. Ortiz Mellet, and J. M. García Fernández, J. Org. Chem., 2014, 79, 11722-11728. M. Aguilar-Moncayo, T. Takai, K. Higaki, T. Mena-Barragán, Y. Hirano, K. Yura, L. Li, Y. Yu, H. Ninomiya, M. I. García-Moreno, S. Ishii, Y. Sakakibara, K. Ohno, E. Nanba, C. Ortiz Mellet, J. M. García Fernández, and Y. Suzuki, Chem. Commun., 2012, 48, 6514-6516.

47. R. Martín, A. Moyano, M. A. Pericàs, and A. Riera, Org. Lett., 2000, 2, 93-95.

48. R. Martín, C. Murruzzu, M. A. Pericàs, and A. Riera, J. Org. Chem., 2005, 70, 2325-2328.

49. A. Singh, B. Kim, W. K. Lee, and H.-J. Ha, Org. Biomol. Chem., 2011, 9, 1372-1380.

50. K. Asano, T. Hakogi, S. Iwama, and S. Katsumura, Chem Commun., 1999, 41-42.

51. S. K. Bagal, S. G. Davies, J. a Lee, P. M. Roberts, P. M. Scott, and J. E. Thomson, J. Org. Chem., 2010, 75, 8133-8146.

52. S. K. Bagal, S. G. Davies, J. A. Lee, P. M. Roberts, A. J. Russell, P. M. Scott, and J. E. Thomson, Org. Lett., 2010, 12, 136-139.

53. H. Byun, L. He, and R. Bittman, Tetrahedron, 2000, 56, 70517091.

54. B. B. Lohray, Synthesis (Stuttg)., 1992, 11, 1035-1052.

55. H. Han, Tetrahedron Lett., 2003, 44, 1567-1569.

56. O. V Singh and H. Han, Tetrahedron Lett., 2003, 44, 2387-2391.

57. M. Alonso and A. Riera, Tetrahedron: Asymmetry, 2005, 16, 3908 3912.

58. O. Simák, J. Stanek, and J. Moravcová, Carbohydr. Res., 2009, 344, 966-971.

59. I. K. Khanna, F. J. Koszyk, M. A. Stealey, R. M. Weier, J. Julien, R. A. Mueller, S. N. Rao, and L. Swenton, J. Carbohydr. Chem., 1995, 14, 843-878.

60. C. Ho, S. D. Popat, T. Liu, K. Tsai, M. Ho, W. Chen, A. Yang, and C. Lin, ACS Chem. Biol., 2010, 5, 489-497.

61. T. Liu, L. Chen, Q. Ma, X. Shen, and Q. Yang, Curr. Pharm. Des., 2014, 20, 754-770.

62. J. Castilla, R. Rísquez, D. Cruz, K. Higaki, E. Nanba, K. Ohno, Y. Suzuki, Y. Díaz, C. Ortiz Mellet, J. M. García Fernández, and S. Castillón, J. Med. Chem., 2012, 55, 6857-6865.

63. J. Castilla, R. Rísquez, K. Higaki, E. Nanba, K. Ohno, Y. Suzuki, Y. Díaz, C. Ortiz Mellet, J. M. García Fernández, and S. Castillón, Eur. J. Med. Chem., 2015, 90, 258-266.
64.

E. M. Sánchez-Fernández, R. Rísquez-Cuadro, M. Chasseraud, A. Ahidouch, C. Ortiz Mellet, H. Ouadid-Ahidouch, and J. M. García Fernández, Chem. Commun., 2010, 46, 5328-5330.

65. P. Alfonso, V. Andreu, A. Pino-Angeles, A. A. Moya-García, M. I. García-Moreno, J. C. Rodríguez-Rey, F. Sánchez-Jiménez, M. Pocoví, C. Ortiz Mellet, J. M. García Fernández, and P. Giraldo, ChemBioChem, 2013, 14, 943-949.

66. H. Suzuki, U. Ohto, K. Higaki, T. Mena-Barragán, M. AguilarMoncayo, C. Ortiz Mellet, E. Nanba, J. M. Garcia Fernandez, Y. Suzuki, and T. Shimizu, J. Biol. Chem., 2014, 289, 14560-14568.

67. R. Kooij, H. M. Branderhorst, S. Bonte, S. Wieclawska, N. I. Martin, and R. J. Pieters, Med. Chem. Comm., 2013, 387-393.

68. D. Bini, F. Cardona, M. Forcella, C. Parmeggiani, P. Parenti, F. Nicotra, and L. Cipolla, Beilstein J. Org. Chem., 2012, 8, 514-521.

69. H. Chen, R. Li, Z. Liu, S. Wei, H. Zhang, and X. Li, Carbohydr. Res., 2013, 365, 1-8.

70. K. W. Hering, K. Karaveg, K. W. Moremen, and W. H. Pearson, J. Org. Chem., 2005, 70, 9892-9904.

71. Y. Yu, T. Mena-Barragán, K. Higaki, J. L. Johnson, J. E. Drury, R. L. Lieberman, N. Nakasone, H. Ninomiya, T. Tsukimura, H. Sakuraba, Y. Suzuki, E. Nanba, C. Ortiz Mellet, J. M. García Fernández, and K. Ohno, ACS Chem. Biol., 2014, 9, 1460-1469. 